\title{
UN NUEVO HITO PARA EL ESTUDIO DE LA POLIORCÉTICA PÚNICA. EL ACCESO EN CODO DE SON CATLAR (CIUTADELLA, MENORCA)*
}

\author{
A NEW MILESTONE FOR THE STUDY OF PUNIC POLIORCETICS. THE "L-SHAPED” \\ GATE OF SON CATLAR (CIUTADELLA, MENORCA)
}

\author{
POR \\ Fernando Prados Martínez $Z^{* *}$ Helena Jiménez Vialás $S^{* * *}$ \\ y OCTAVIO TORRES GOMARIZ ${ }^{* * * *}$
}

\section{RESUMEN - ABSTRACT}

Enmarcado en un proyecto de investigación que estudia la presencia fenicio-púnica en Menorca se desarrollan intervenciones arqueológicas en el poblado de origen talayótico de Son Catlar (Ciutadella), el único de la isla que conserva el perímetro amurallado completo. En este trabajo presentamos el reciente hallazgo de un acceso en codo abierto en el frente occidental del recinto. El reconocimiento de anomalías en este sector del encintado -mediante fotografía aérea y posterior comprobación sobre el terreno-, motivó una excavación arqueológica en extensión. Se trata de un importante descubrimiento pues es la primera estructura de este tipo localizada en el contexto balear y una de las pocas intervenidas con rigor metodológico. La excavación ha permitido documentar que este acceso fue construido en el siglo III a. C., cortando el paño original, y que fue cegada poco después, tras la conquista de la isla por Q. Cecilio Metelo hacia el año 123 a. C.

As part of a research project studying the Phoenician-Punic presence in Menorca, archaeological interventions were carried out in the Talayotic settlement of Son Catlar (Ciutadella), the only one on the island where the entire walled perimeter is preserved. We present in this work the recent finding of an "L-shaped" gate open on the western front of the enclosure. The recognition of anomalies in this sector -through aerial photography and subsequent verification on the ground- led to an extensive archaeological excavation. The relevance of this finding lies in being the first structure of this type located in the Balearic context and one of the few properly excavated and published. The archaeological works have documented that this access was built in the 3rd century BC, cutting the original wall, and walled up soon after, following the conquest of the island by Q. Cecilio Metelo around 123 BC.

* Este trabajo se inscribe en el Proyecto de investigación Modular: Arquitectura fenicio-púnica de Menorca (web.ua.es/ es/modular/) financiado por el Consell Insular de Menorca y cuenta con el apoyo del Camping Cap-Blanch, el INAPH de la Universidad de Alicante y el CEPOAT de la Universidad de Murcia. Se nutre de un importante equipo científico conformado por M. J. León (Museu de Ciutadella), J. C. De Nicolás (IME), A. M. Adroher (Universidad de Granada), J. J. Martínez (Universidad de Murcia), M. Fructuoso y S. Carbonell (Universidad de Alicante), a quienes agradecemos su dedicación.

** Universidad de Alicante, Instituto Universitario de Investigación en Arqueología y Patrimonio Histórico (INAPH), fernando.prados@ua.es / ORCID iD: https://orcid.org/0000-0001-8441-8508

*** Universidad de Murcia, Grupo de investigación E041-04 y Centro de Estudios del Próximo Oriente y la Antigüedad Tardía, vialas@um.es / ORCID iD: https://orcid.org/0000-0002-9679-6968

**** Universidad de Alicante, Instituto Universitario de Investigación en Arqueología y Patrimonio Histórico (INAPH), investigador predoctoral contratado (programa propio de I+D+i, FPU-UA2015), octavio.torres@ua.es / ORCID iD: https://orcid.org/0000-0002-1933-5551 


\author{
Palabras Clave - Keywords \\ Islas Baleares; fortificación; guerras púnicas; talayótico; conquista romana. \\ Balearic Islands; fortification; Punic wars; Talayotic; Roman conquest.
}

\title{
Cómo citar este ARTículo / Citation
}

Prados Martínez, F.; Jiménez Vialás, H. y Torres Gomariz, O. (2021): «Un nuevo hito para el estudio de la poliorcética púnica. El acceso en codo de Son Catlar (Ciutadella, Menorca)». Gladius, 41: 25-43. https://doi. org/10.3989/gladius.2021.02

RECIBIDO / RECEIVED: 24-04-2020

ACEPTADO / ACCEPTED: 19-04-2021

\section{INTRODUCCIÓN. UN PROYECTO SOBRE ARQUITECTURA PÚNICA Y MENORCA COMO CAMPO DE ESTUDIO}

La importancia de este trabajo radica fundamentalmente en la novedad que supone el hallazgo de una estructura defensiva de esta naturaleza en el contexto de Menorca. Un ámbito que, por lo general, ha permanecido fuera de los estudios sobre la presencia fenicio-púnica y de los escenarios principales del conflicto romano-cartaginés, pese a la referencia específica de Tito Livio que señala la llegada de la flota comandada por Magón Barca a la Balearis minor en el invierno del 206-205 a. C. (Livio XXVIII, 37, 5-10). Al revisar la documentación sobre la presencia colonial fenicia y púnica en el Mediterráneo central y occidental, Menorca queda como una incógnita, unas veces introducida sin más como un vértice más de esa presencia, al mismo nivel que Mallorca e incluso Ibiza, y otras veces directamente al margen, como si hubiese sido completamente ajena a este proceso histórico y cultural. Las razones son variadas y no ha lugar en este texto como para poder detallarlas, aunque sí vamos a señalar las dos que consideramos más importantes: la falta de estudios específicos enfocados a resolver esta cuestión, por un lado, y por otro, la enorme personalidad y poder de atracción científico y social que ha tenido la cultura talayótica que floreció durante la Prehistoria y que ha eclipsado otras fases de la historia insular.

El proyecto en el que se enmarca este trabajo vino precisamente a tratar de dar respuesta a ese interrogante casi atávico ¿hubo en Menorca una presencia fenicia y púnica como en el resto de las islas Baleares? De ser así ¿era posible rastrearla a través de la arquitectura aprovechando el enorme patrimonio insular? Era evidente que en este fecundo terreno arqueológico el estudio del impacto fenicio-púnico estaba en clara desventaja en comparación con otras fases históricas, mucho mejor conocidas, como la talayótica, postalayótica ${ }^{1}$ o romana (Plantalamor, 1991; Guerrero et alii, 2002; Orfila, 1995 y 2008, entre otros). Mientras que el análisis de dichos periodos fue beneficiando el estudio de distintos yacimientos y propiciando excavaciones arqueológicas desde principios del siglo XX, el impacto de la presencia e influencia fenicio-púnica se ha venido nutriendo de hallazgos casuales, excavaciones de urgencia en el mejor de los casos y materiales procedentes de expolios (por ejemplo, Castrillo, 2005; De Nicolás, 2014 y 2017; Ramon y Pons, 2017).

Por todo ello, se planteó un estudio sobre distintos enclaves (Fig. 1), tanto arquitectónico como de territorio (Prados et alii, 2015), apoyado en una metodología definida como "no invasiva", es decir, se ejecutaron prospecciones superficiales ( $\sin$ recogida de material, siendo este únicamente documentado in situ) y se aplicó la llamada "arqueología de la arquitectura" (basada en nuestro caso en lecturas paramentales, elaboración de fichas, topografía y documentación fotogramétrica en 3D). Tras esa primera fase, desde 2017 se han planteado excavaciones arqueológicas en el poblado de Son Catlar, que nos ocupa en estas páginas (Fig. 2). La razón es que las formas arquitectónicas, sobre todo cuando estas exhiben

\footnotetext{
1 Sin ánimo de entrar en la cuestión cronológica y terminológica, que suscita encendidas controversias entre los especialistas, podemos dividir la fase final de la Prehistoria de Menorca, previa a la conquista romana, en dos periodos: talayótico y postalayótico, equivalentes en líneas generales con el Hierro I y Hierro II (Guerrero et alii, 2002).
} 


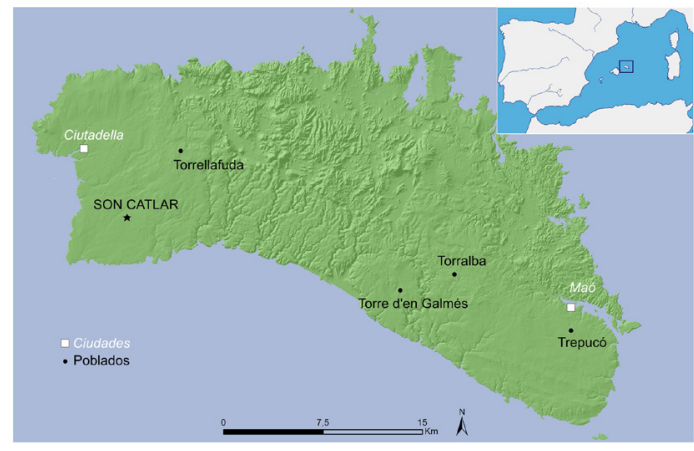

Figura 1. Mapa de Menorca con indicación de los principales yacimientos estudiados por el proyecto "Modular".

una gran personalidad como sucede en el mundo talayótico, se convierten en uno de los rasgos más elocuentes de la idiosincrasia de una sociedad, y su estudio permite detectar cambios, añadidos y adaptaciones, por pequeñas que sean. Hasta la fecha, la investigación está ofreciendo importantes resultados que ya han sido presentados en diversos congresos (Prados et alii, 2015 y 2017a; Torres, 2016). Asimismo, se ha editado una primera monografía en la que junto a diversos especialistas sobre la cultura fenicia y púnica participaron investigadores insulares con la intención de generar una obra coral, status quaestionis, y que trató de ordenar la información dispersa (Prados et alii, 2017b).

\section{UN PODEROSO SUJETO DE ESTUDIO. LAS FORTIFICACIONES PRERROMANAS EN MENORCA}

Aunque en el proyecto también se contempla el estudio de otras manifestaciones construidas tales como las casas (Torres, 2016 y 2017) o las tumbas (Carbonell, 2017), son las fortificaciones, debido a lo expresivo de muchos de los elementos que fueron detectados desde los primeros trabajos, las que nos han ocupado con detalle inicialmente.

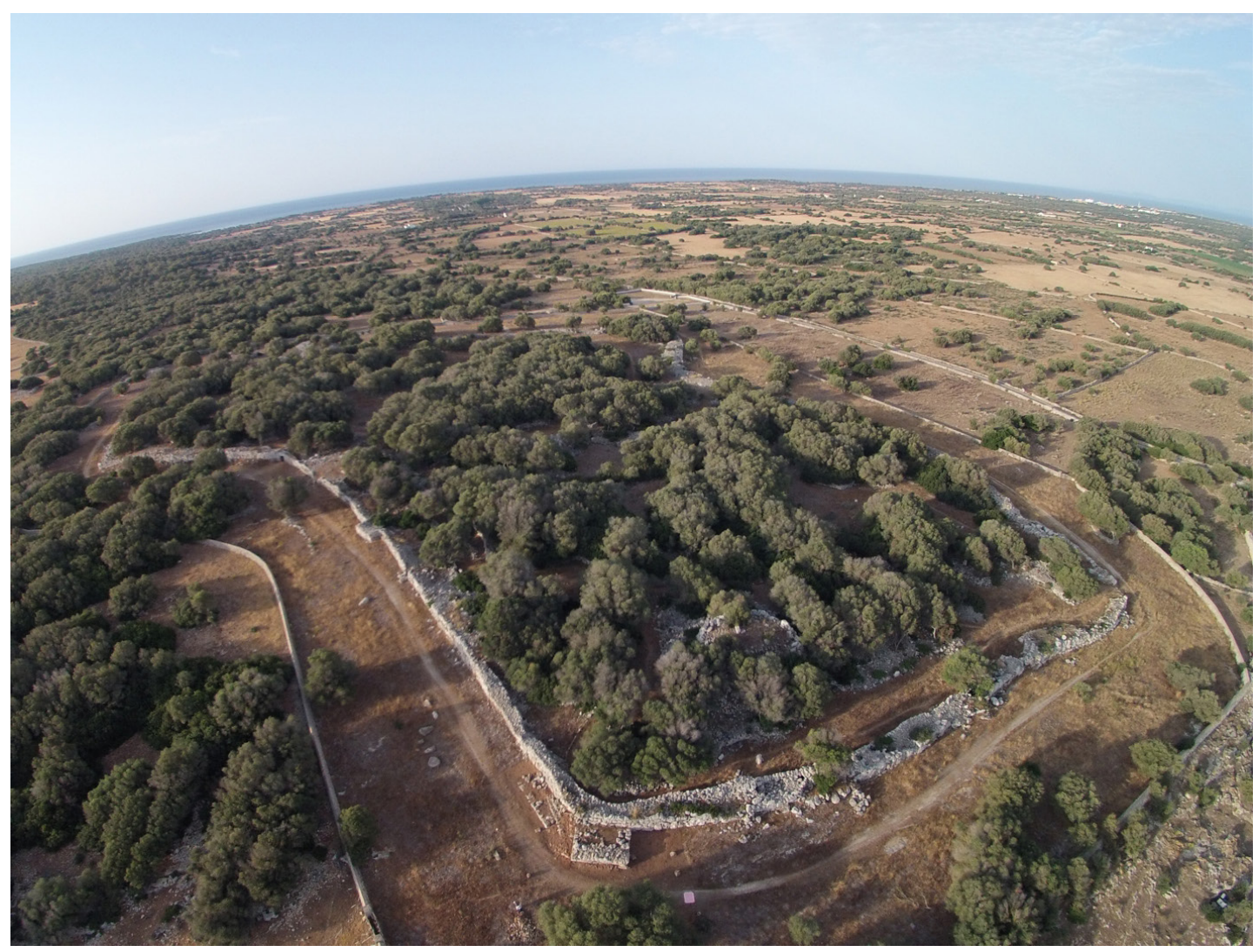

Figura 2. El poblado de Son Catlar desde el norte. En primer término, los bastiones de esquina; al fondo, el mar Mediterráneo. Fotografía: Proyecto Modular. 
Sabemos que de entre todas las manifestaciones construidas serán las de carácter militar, además, las que unan a las últimas novedades arquitectónicas, por razones obvias, rasgos de tipo identitario, simbólico e incluso religioso. Todo ello conforma un dosier de estudio magnífico para tratar de dar respuesta a las dudas sobre la incidencia externa en las sociedades de tradición talayótica. Uno de los indicadores más precisos de la consolidación de un proyecto político y económico es el desarrollo de una fortificación (Garlan, 1992). La muralla en el mundo antiguo, que era parte sustancial de la ciudad, se fue convirtiendo en expresión del trabajo mancomunado reflejo de la población que la construyó (Leriche y Tréziny, 1982). Las murallas tuvieron un perfil "proléptico", como imagen proyectada al exterior de la ciudad y de los ciudadanos (Greco y Torelli, 1983), algo así como una carta de presentación (Moret, 1998: 84). Junto a su rol defensivo, la fortificación tenía un carácter simbólico y religioso, al delimitar el espacio habitado del territorio circundante (Berrocal-Rangel, 2004). En Menorca, desde el punto de vista identitario, la construcción de la muralla vino a sustituir a los talayots como expresión del trabajo colectivo. Un acontecimiento de la magnitud de la construcción de una fortificación, por lo que conlleva de desarrollo técnico y de trabajo en grupo, ha de vincularse a un momento clave del desarrollo social de los grupos postalayóticos.

En la isla parecen constatarse defensas organizadas con perímetros de entre 500 y $1000 \mathrm{~m}$ que la mayor parte de las veces dejaron fuera parte del caserío por razones de tiempo y esfuerzo. De esta forma eran más fáciles de defender, sobre todo cuando la población, como posiblemente sucedió en Menorca, no era numerosa. A primera vista, en estas murallas se observan elementos ajenos a la tradición constructiva local, pero propios de las fortificaciones mediterráneas tales como poternas, bastiones de planta rectangular que sobresalen poco de los lienzos, paramentos dobles con casamatas, sistemas de flanqueo con lienzos en cremallera y cóncavos, plataformas para ubicar maquinaria de torsión, y adarves. Muestra del valor único y representativo de las murallas menorquinas es que sus mejores paralelos se encuentran en Grecia y en el mundo púnico centro-mediterráneo (Frederiksen, 2011; Prados y Jiménez, 2017). Las defensas de los poblados menorquines se distinguen también de otros casos insulares por ser reflejo de un nivel de organización territorial sin precedentes. Si se observan los poblados amura- llados con soluciones defensivas complejas, parecen definirse dos áreas fortificadas en el entorno de los dos principales puertos de la isla (Maó y Ciutadella) (Jiménez et alii, 2017). Esto es reflejo de la intervención de un poder político capaz de impulsar, controlar y costear la obra, y de la presencia de arquitectos o militares experimentados encargados de su realización, según criterios tanto funcionales como estéticos.

Para las culturas insulares, las murallas supusieron una evidente evolución hacia lo urbano y un reflejo material, tangible, del inicio de una nueva época. En el poblado de Torre d'en Galmés (Alaior) por ejemplo, se ha atribuido la construcción de su defensa a la necesidad de control territorial (Plantalamor, 1991: 249). Al igual que sucedió en culturas contemporáneas como la ibérica (Moret, 1998: 83) parece que las comunidades postalayóticas fueron capaces de desarrollar programas defensivos complejos, adaptados a un nuevo horizonte bélico, y ello ha de percibirse en un proceso histórico de larga duración.

Las murallas menorquinas reflejaron la incorporación paulatina de las novedades técnicas que caminaron al unísono de las colonizaciones protagonizadas por fenicios, griegos, cartagineses y romanos, y de los nuevos escenarios bélicos. Con la fortificación se fueron incorporando novedades técnicas de carácter arquitectónico que se habían desarrollado exitosamente antes en el Mediterráneo central y oriental desde el Bronce Final (Cecchini, 1995: 389). La defensa de la comunidad no solo implicaba el esfuerzo de la construcción, sino que suponía que la sociedad que la desarroló se encontraba perfectamente coordinada para organizar y hacer efectiva su función, repartiendo las tareas. Para organizar la salvaguardia de los poblados era necesaria una participación social ordenada que solo pudo partir de una estructura política y económica fuerte y desarrollada, capaz de canalizar los esfuerzos primero en la ejecución de la obra y después en su gestión.

Por otra parte, a tenor de los datos que manejamos por nuestras excavaciones y los recogidos en otras publicaciones, ninguna de las murallas insulares se puede fechar con certeza antes del siglo VII a. C., lo que directamente se corresponde, en función de lo que dictaminan los materiales arqueológicos muebles, con la apertura de Menorca al Mediterráneo a través de la presencia de agentes comerciales. Ello se reflejará, como es lógico, en una sensación de peligro constante, a la par que se constatarán diversos cambios. También se puede 
asociar el auge de las fortificaciones en los poblados con el fin de los talayots. Con las defensas llegaron a Menorca materiales importados (Juan et alii, 2004), nuevas especies de animales (Ramis, 2017), pero también la intimidación y el miedo. La muralla cubría, por un lado, las expectativas simbólicas, pero también atenuaba la sensación de miedo que se había incorporado a esta sociedad. Con anterioridad, parece que los poblados talayóticos estaban despreocupados por sus defensas o que, al menos, consideraban cubiertas sus necesidades de protección con los propios talayots. La inserción de Menorca dentro de las redes de comercio a escala internacional trajo consigo riqueza, sin duda, pero también la necesidad imperiosa de protegerse y de intimidar al potencial atacante. Los nuevos "enemigos" no solo eran las potencias comerciales y militares que surcaban el Mediterráneo, sino las distintas actividades piráticas de las que las fuentes textuales han dejado abundante información (Orfila, 2008; Puig, 2013; Domínguez Monedero, 2014).

A pesar de que se conservan pocos restos, siendo Son Catlar el conjunto defensivo más completo, se puede distinguir la naturaleza de cada uno y su adaptación a lo que se requería de ellos. Las primeras murallas menorquinas eran de tipo "pasivo", lo que quiere decir que estaban preparadas para resistir envites puntuales, por conflictos locales, o esos ataques piráticos que tenían la intención de saquear los poblados. Cabe aclarar que con "pasivo" no queremos decir que no permitiese el ataque, pues para lanzar proyectiles no es necesaria maquinaria. Se erigieron con enormes bloques que conformaban paramentos ciclópeos que recordaban en parte a los propios talayots, sirviéndose de ellos en algún caso como cantera. En este gesto se ha de ver algo más que un ahorro de tiempo y esfuerzo, ya que las primeras murallas surgen en el momento de abandono de los talayots. Pese a ello, los rodeaban, girando el lienzo a su alrededor con la intención de que siguiesen integrados en el poblado, como parte consustancial de la comunidad. Así hemos de entender, por ejemplo, por qué los cinco talayots del poblado de Son Catlar determinan cada uno de los giros de la muralla para quedar inscritos dentro (Fig. 3). Las murallas de tipo "pasivo" eran muy anchas, elevadas y trataban de exponer al potencial enemigo el menor número de debilidades. Por ello apenas tenían puertas, y estas, en muchas ocasiones, tenían la forma de poternas o pequeños portillos que permitían salir y entrar sin apenas ser visto $y$,

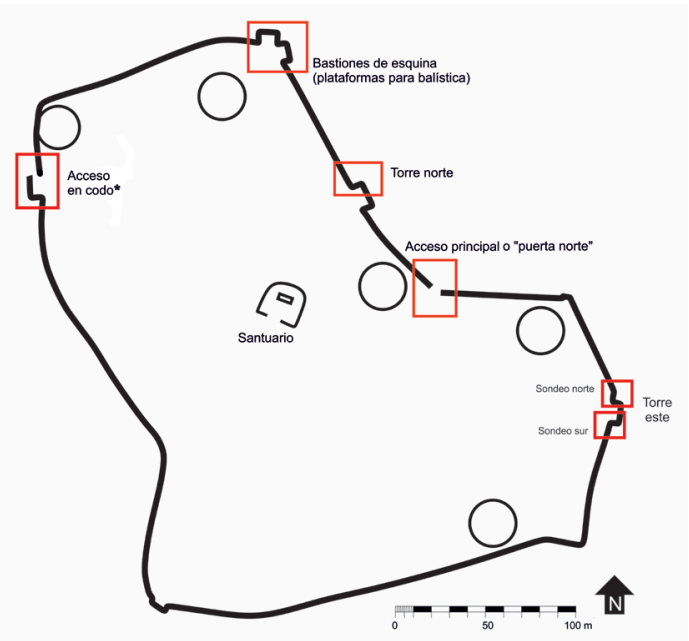

Figura 3. Planta esquemática con indicación de las zonas excavadas. El asterisco marca el lugar del hallazgo del acceso en codo. Dibujo: Proyecto Modular.

sobre todo, poder bloquearse rápidamente en caso de peligro.

Nuevos riesgos y nuevas necesidades provocaron que las viejas defensas "pasivas" se fueran convirtiendo en "activas" en un segundo momento. La muralla "activa" de la que en Menorca contamos con varios ejemplos (como la de los poblados de Trepucó, Torrellafuda o Son Catlar) no solo estaba configurada para proteger a los habitantes del poblado, sino que era capaz de contraatacar al enemigo, a través de todo un elenco de soluciones arquitectónicas complejas diseñadas para tal efecto. Defensa y ataque son elementos fundamentales en la guerra como sabemos, por eso las técnicas de defensa iban íntimamente ligadas a las novedades en las técnicas de ataque y asedio (Quesada, 2007: 76). Las adaptaciones que se observan en las murallas de Trepucó, Torrellafuda o Son Catlar, donde se incluye el acceso que aquí se presenta, no deben en caso alguno explicarse únicamente por una conflictividad social interna, a escala local, pues presentan técnicas propias del nuevo horizonte bélico desarrollado a escala mediterránea desde el s. V a. C. El motivo hubo de ser, o bien las guerras púnicas, que enfrentaron a las dos grandes potencias del momento, Roma y Cartago, o la conquista romana de las Baleares, acaecida en el 123 a. C., que actuó sobre un sustrato autóctono que había sido afín a la causa cartaginesa y parte de su órbita cultural. Las excavaciones arqueológicas de Son Catlar están encaminadas precisamente a constatar con docu- 
mentación arqueológica que si la primera muralla se levantó hacia el siglo VI a. C., fue adaptada a las nuevas necesidades militares a lo largo del siglo III a. C. en el marco del citado conflicto romano-cartaginés que, como veremos ahora, tuvo a Menorca como uno de sus escenarios.

\section{EL POBLADO AMURALLADO DE SON CATLAR Y LA REFORTIFICACIÓN DEL SIGLO III A. C.}

El estado de conservación de Son Catlar (Fig. 2) y la naturaleza de su espectacular muralla, con su perímetro completo, hacían de este poblado el más propicio para tratar de alcanzar los objetivos planteados (Jiménez et alii, 2019). Las primeras tareas de naturaleza no invasiva que se realizaron, y que hemos referido en el apartado anterior, permitieron conocer en profundidad la fortificación y observar en algunos puntos hasta tres y cuatro fases distintas; pero los datos debían ser ratificados a partir de la realización de intervenciones arqueológicas de tipo estratigráfico, que permi- tiesen distinguir estas fases con detalle y atribuir unas dataciones precisas.

La lectura paramental, la fotogrametría y las imágenes en alta definición tomadas desde un dron evidenciaban diversas anomalías y refacciones en el trazado. También el citado conjunto de bastiones adosados que caracterizan esta muralla debía adscribirse a fases más recientes que la del trazado primitivo. Sabíamos que Son Catlar, que tuvo sus orígenes a finales de la Edad del Bronce, adquirió su máximo desarrollo poco antes de la conquista romana, a tenor de los diversos estudios publicados (Plantalamor y Rita, 1982; Plantalamor, 1991; Juan et alii, 1998). Según los trabajos arqueológicos que hemos efectuado, fue hacia el siglo VI a. C. cuando se reforzó con un lienzo murario de cerca de $900 \mathrm{~m}$ de longitud que supera en algunos puntos los $6 \mathrm{~m}$ de espesor. Esta datación proviene de muestras de fauna obtenidas en las cimentaciones de distintos puntos intervenidos de la fortificación (muestras BETA-475669, 595411 cal BC, y BETA-538430, 774-482 cal BC, y BETA-538431, 768-476 cal BC), si bien podría retrasarse un siglo la refacción de algún sector por el hallazgo de fragmentos anfóricos púnico-ebu-

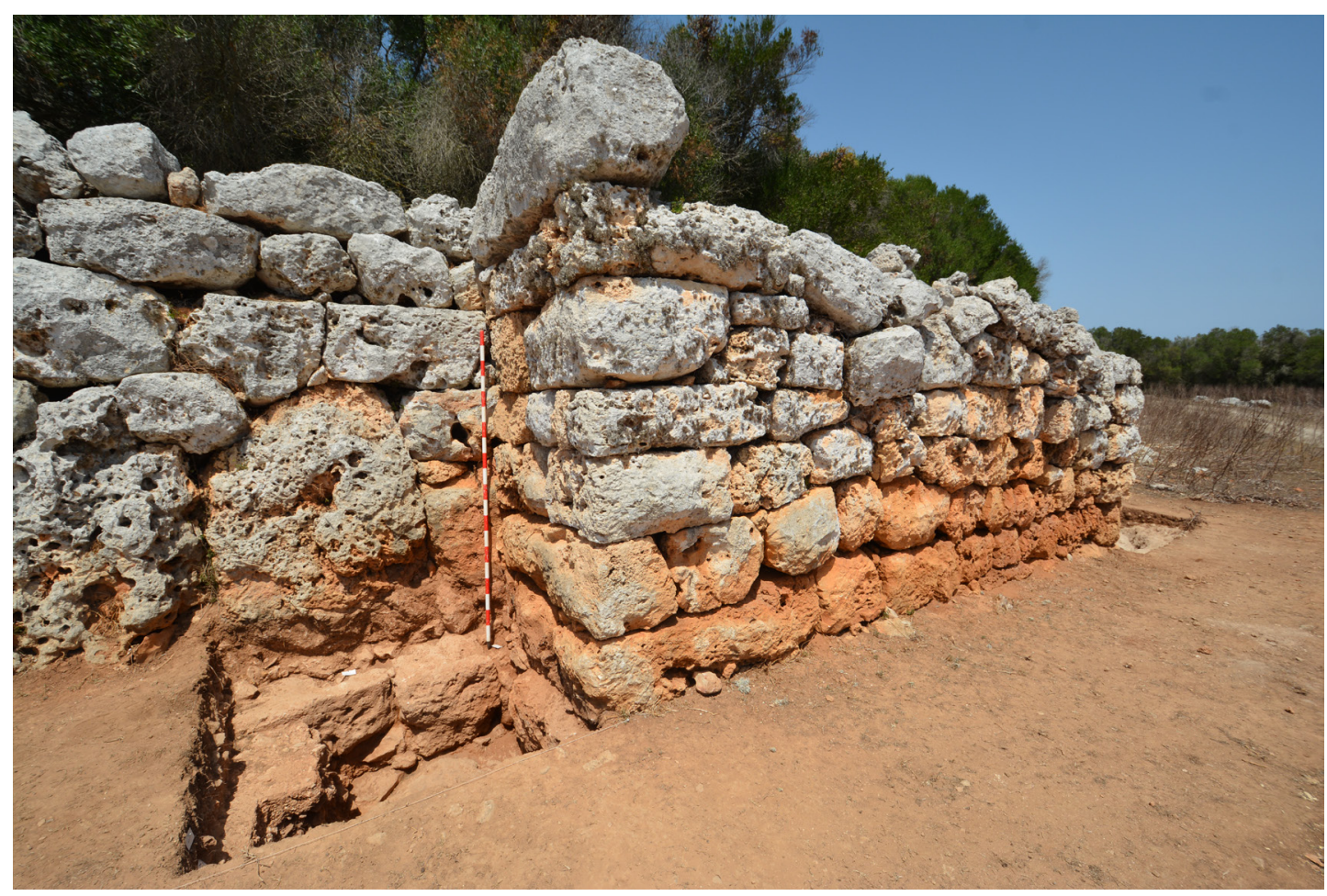

Figura 4. Sondeo diagnóstico realizado en la torre norte en 2017. Se observa la zapata y el lienzo original (s. VI a. C.) y la torre adosada (s. III a. C.). Fotografía: Proyecto Modular. 
sitanos en la base del sondeo que se realizó en el bastión este (en concreto ánforas PE 14 / Ramon T-8.1.1.1).

El lienzo originario, que no será objeto de este trabajo, se adaptó siglos después al nuevo panorama militar y se dotó de los más adelantados sistemas defensivos. La clave era poder responder ataques de ejércitos que contaban con armamento avanzado y desarrollado y, sobre todo, con capacidad de organizar asedios. Por eso consideramos que los bastiones adosados al primer lienzo (Fig. 4) y otras adaptaciones de la muralla de Son Catlar no responden a una conflictividad local, ya que son soluciones defensivas características del nuevo horizonte bélico desarrollado a escala mediterránea desde el siglo V a. C., ligado a las guerras de Sicilia, y que se puso en práctica en centros urbanos del Mediterráneo occidental desde el siglo III a. C. Las defensas de Son Catlar reúnen un magnífico conjunto de construcciones poliorcéticas: la muralla y sus obras avanzadas (bastiones, antemurales) puertas y poternas, plataformas para artillería y casamatas. Los lienzos presentan, además, un estado de conservación muy propicio para poder ser analizados con detalle (Fig. 5).

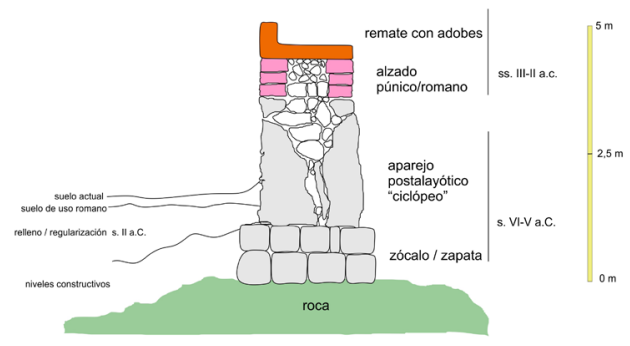

Figura 5. Sección del lienzo primigenio. El esquema del alzado reúne los datos obtenidos en las excavaciones. Dibujo: Proyecto Modular.

Al contrario que las defensas "pasivas" iniciales, esta refortificación transformó la muralla de Son Catlar en "activa", capaz de poder "contraatacar" al enemigo. Ya hemos aludido a que presenta bastiones adosados e incluso dos ejemplares visibles en el ángulo noreste del poblado, como flanqueo (Fig. 3), cuya excavación confirmó que eran coetáneos y funcionaron a la vez (Prados y Jiménez, 2017: 125; Prados et alii, 2017a). Estos bastiones se orientaron en dos direcciones para cubrir los flancos y, por su tamaño, poder albergar piezas de balística que fuesen útiles a la hora de defenderse y disuadir a enemigos con capacidad de asediar. De hecho, la existencia de maquinaria de torsión se confirma por el hallazgo de proyectiles, seguramente lithoboloi de ballista por su tamaño, junto a la muralla, algunos en contexto y aparentemente golpeados por impactos. Tanto estos dos bastiones como el resto de los adosados presentan técnicas constructivas y medidas compatibles con las púnicas que se conocen (Prados, 2008), concretamente el uso sistemático de un codo de 0,52 m aplicado en módulos de 3 y sus múltiplos, un rasgo visible en otros recintos como los de Erice (Sicilia), Kerkouane (Túnez) y, mucho más cerca, en el Tossal de Manises (Alicante), Castillo de Doña Blanca y Carteia (Cádiz), o Cartagena (Murcia).

Según apuntan los materiales localizados, estas defensas se organizaron ya en el siglo III a. C., posiblemente hacia el último cuarto de esta centuria, coincidiendo con la conversión de Menorca en un escenario más del gran conflicto protagonizado por Roma y Cartago. Junto a alguna datación radiocarbónica se ha recuperado cultura material datable a lo largo del siglo III a. C., que la investigación reciente ha convertido en fósiles directores de la época bárquida tales como fragmentos de vajilla fina de barniz negro del tipo "pequeñas estampillas", de $k a$ lathos ibérico y de ánfora púnico-ebusitana $\mathrm{PE}$ 15 / Ramon T-8.1.2.1 y PE 16 / Ramon T-8.1.3.1 (Ramon, 1995; Ruiz, 2004; Ramallo et alii, 2013; Ruiz et alii, 2013). La exhumación de estas piezas en la cimentación del bastión noroeste arroja luz sobre la cronología y construcción de este sistema defensivo, que situamos a finales del siglo III a. C. Junto a este lote de material, la documentación arqueológica obtenida indica otro dato de enorme relevancia: los bastiones intervenidos hasta el momento habían sido ya amortizados al principio de la presencia romana, tras la conquista de la isla por el cónsul Metelo (cuyo cognomen ex virtute era "baleárico"). Los hallazgos de materiales de desecho vertidos extramuros son evidentes, sobre todo cuando todos ellos pertenecen a un momento que podemos situar grosso modo hacia el año 100 a. C. Algo similar sucedió en el acceso en codo que a continuación se estudiará con más detalle. 


\section{EL “ARTE DE DEFENDER" SON CATLAR. EL HALLAZGO Y LA EXCAVACIÓN DEL ACCESO EN CODO}

Enmarcada en las actuaciones descritas que tuvieron como fin documentar y tratar de fechar esas anomalías observadas en el trazado murario, se intervino en el tramo occidental, donde también se había detectado en prospección una estructura extramuros arrasada hasta el nivel de cimentación. A primera vista, esta estructura, conformada con una hilada de mampuestos, parecía ser otro bastión más adosado al lienzo original, pero que había sido desmontada hasta la base (Fig. 6). Dos argumentos planteaban problemas para admitir esta hipótesis, primero, que tras el desbroce del sector se comprobó que la alineación de bloques que discurría frente a la muralla era más grande que la del resto de bastiones del recinto, y segundo, que el lienzo de la muralla aparecía claramente alterado por añadidos modernos en ese sector. La cadencia de ortostatos de la muralla se interrumpía justo donde afloraba esta alineación, y el espacio intermedio estaba claramente rellenado por piedras menudas, amontonadas en forma de claper, término menorquín empleado para denominar los majanos o acumulaciones de piedra modernos (ver la foto vertical de la Fig. 7).

La realización de fotografías aéreas detalladas de la zona y la lectura de paramentos permitió comprobar que el tramo de muralla estaba en efecto interrumpido, y que el lienzo era mucho más angosto en ese sector, pese a que en la zona había restos de un antiguo talayot desmontado, seguramente empleado como cantera para construir la muralla. Con un supuesto bastión delante era imposible plantear que esta zona hubiese sido derribada en época antigua, y mucho menos por maquinaria de asalto. El ancho medio de la muralla y el bastión imposibilitarían esta acción, de igual manera que era insostenible pensar en procesos postdeposicionales como los causantes de las anomalías. Por todo ello se planteó una intervención arqueológica en área, desarrollada en sendas campañas, una primera en 2017 en la parte delantera, donde se documentaba la alineación de bloques, y la segunda, consecuencia de los resultados de la primera, en 2019 y ya directamente sobre el encintado.

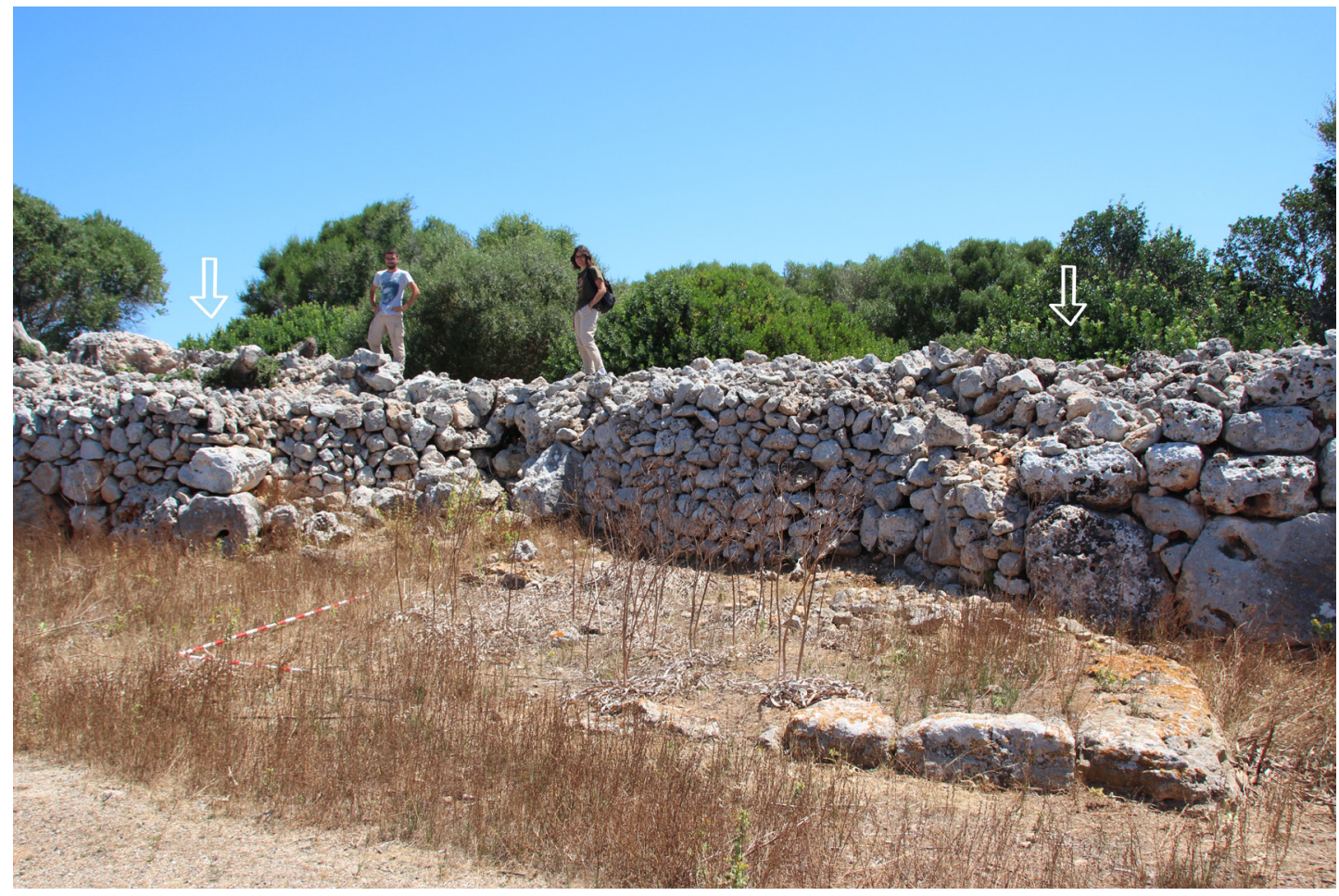

Figura 6. La zona del acceso en codo durante el reconocimiento previo (prospección de 2016). Las flechas indican los puntos donde la muralla se interrumpe y se observa la anomalía central. Fotografía: Proyecto Modular. 

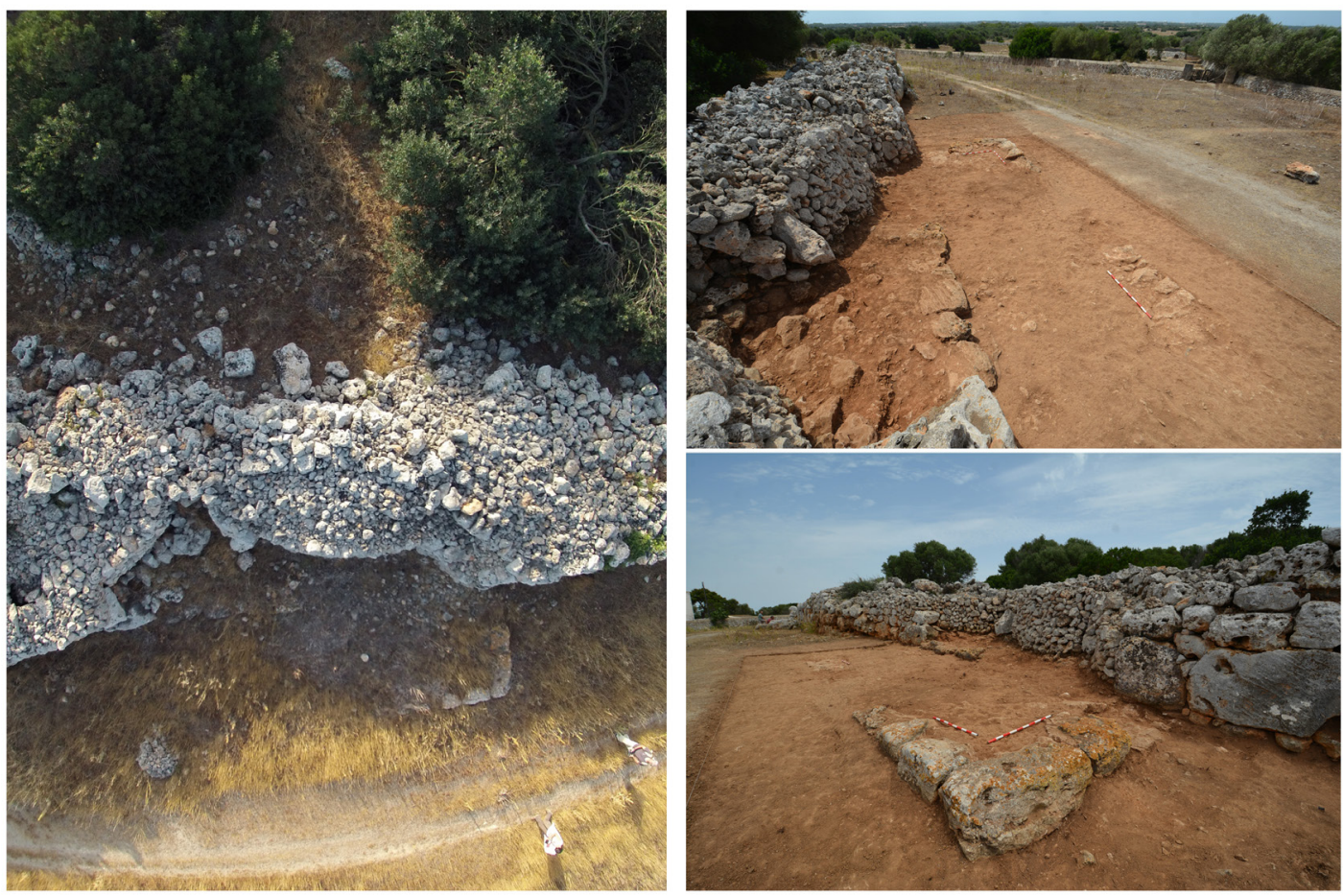

Figura 7. Secuencia del proceso de documentación del acceso en codo. Foto aérea y vistas desde el norte y desde el sur. Fotografía: Proyecto Modular.

El avance de la excavación permitió, como se aprecia en las imágenes que acompañan el texto, documentar que lo que parecía un bastión en realidad era un parapeto de aproximadamente $1,60 \mathrm{~m}$ de anchura (equiparable a 3 codos de $0,525 \mathrm{~m}$, es decir, la misma unidad de medida que se apreciaba en los bastiones) y que entre este y el frente de la muralla quedaba un espacio hueco de la misma dimensión. Este hecho, junto a los comentados antes, nos llevó a barajar la posibilidad de encontrarnos ante una obra avanzada, que solo tendría razón de ser si estaba protegiendo un vano. Esto explicaría que detrás el lienzo estuviese interrumpido (Fig. 6). Además, unos pocos metros al sur se localizaba una poterna de la fase primitiva de la muralla, que había sido tapiada concienzudamente. La suma de todos estos factores permitió plantear que estábamos ante un acceso en codo, similar al de la fase púnica de la ciudad de Carteia, o al de la "porte du Couchant" de Kerkouane (Blánquez et alii, 2006: 135; Prados, 2008; Fantar, 1986: 242, fig. 119; Montanero y Asensio, 2009), como veremos en el siguiente apartado.

Con estos datos se solicitó autorización para desmontar los clapers, pues se trata de elemen- tos etnográficos protegidos por el departamento de cultura del Consell Insular. Tras la visita técnica y obtenido el visto bueno, procedimos a quitar los añadidos, una vez documentados, y así se localizó una pequeña garita o casamata aneja al acceso (Fig. 8, en primer término), que venía a añadir información a lo que se había convertido en algo más que una mera hipótesis de trabajo. La intervención arqueológica desarrollada en paralelo permitió documentar por completo el parapeto o antemural, y cómo este se adosaba al lienzo original en ángulo recto (Fig. 7, derecha). Al tiempo, se pudo comprobar que la estructura avanzada había sido arrasada hasta la cimentación, pudiendo recuperar abundantes materiales arqueológicos tanto de los niveles de base como de las interfaces de arrasamiento. En la zona de entrada, entre el parapeto y la muralla, se veían las improntas, a modo de mochetas, de los ejes del gozne de una puerta. Más adelante, se apreciaba cómo toda la obra se había levantado modificando el lienzo original postalayótico, desmontado hasta su característico zócalo (como se observa en la Fig. 4 y en el esquema de la Fig. 5). A pocos metros de la puerta se pudo excavar un depósito con restos humanos, 


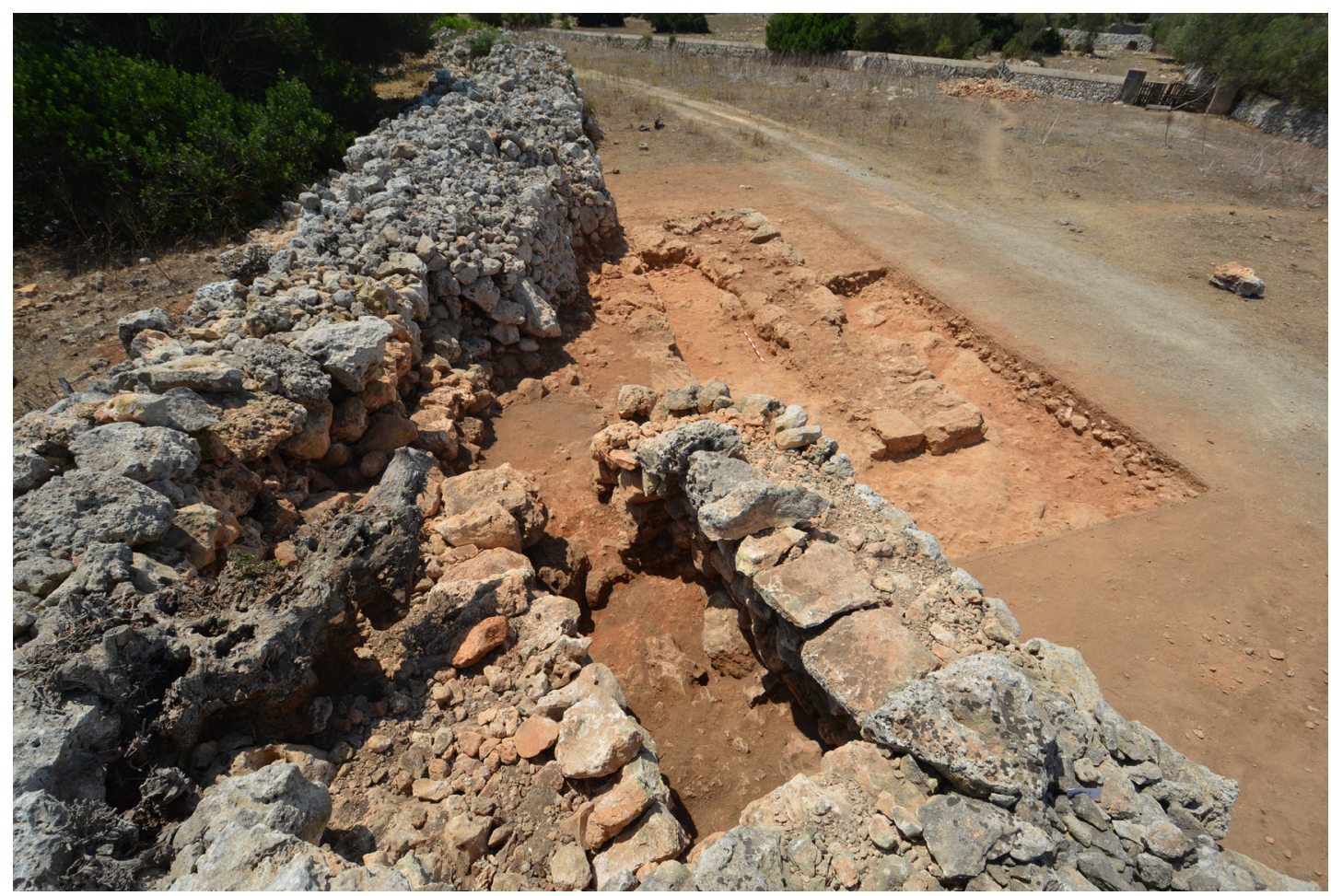

Figura 8. El parapeto y la garita/casamata lateral al final de la campaña de 2017. Fotografía: Proyecto Modular.

algunos en posición anatómica y de un altísimo interés, que pasaremos a describir con detalle en el apartado siguiente.

La documentación avalaba la necesidad de continuar con la intervención, y así se ejecutó la segunda campaña, que empezó por desmontar por completo los añadidos modernos, siempre de forma ordenada, metódica y previa documentación. Así es como se localizó un paramento muy somero, que conservaba cuatro hiladas, levantado de una vez, y que claramente bloqueaba el acceso al interior del poblado (Fig. 9). La estratigrafía era sencilla y permitía vislumbrar cómo la muralla original había sido desmontada para construir el acceso en codo, y que una vez arrasado, se había levantado este murete para bloquear el paso. Este muro descansaba sobre los niveles de circulación y arrasamiento de la puerta, y se apoyaba tanto en el paramento de la muralla primigenia como sobre los dos ortostatos colocados a modo de jamba (Fig. 10).

Finalmente, este muro de cegado fue también desmontado parcialmente durante la excavación para proceder a la documentación del vano de acceso, tratando de localizar los niveles de circulación y detectar elementos arqueológicos que nos permitiesen fechar todos estos procesos de construcción/uso/amortización. La imagen aérea de toda la zona de intervención (Fig. 11) permite observar con cierto detalle todo lo que se acaba de comentar, y apreciar la relevancia que consideramos tiene este hallazgo.

\section{LOS CONTEXTOS ARQUEOLÓGICOS Y CULTURALES}

Una vez descrito el hallazgo y la excavación del acceso, vamos a concentrarnos ahora en los contextos, tanto los estratigráficos en sí, como los culturales relativos a este tipo de obras defensivas. Junto a la novedad que ha supuesto este descubrimiento, cabe subrayar también la riqueza de materiales arqueológicos aparecidos que han permitido fechar los distintos procesos descritos.

En la parte exterior, el arrasamiento al que fue sometido el parapeto impidió que conservase el alzado. Como se aprecia en las imágenes (Figs. 7 y 8 ) apenas si levanta 20 o $30 \mathrm{~cm}$ por encima de la roca base. Pese a ello, pudimos documentar un amplio estrato de destrucción en el que se 


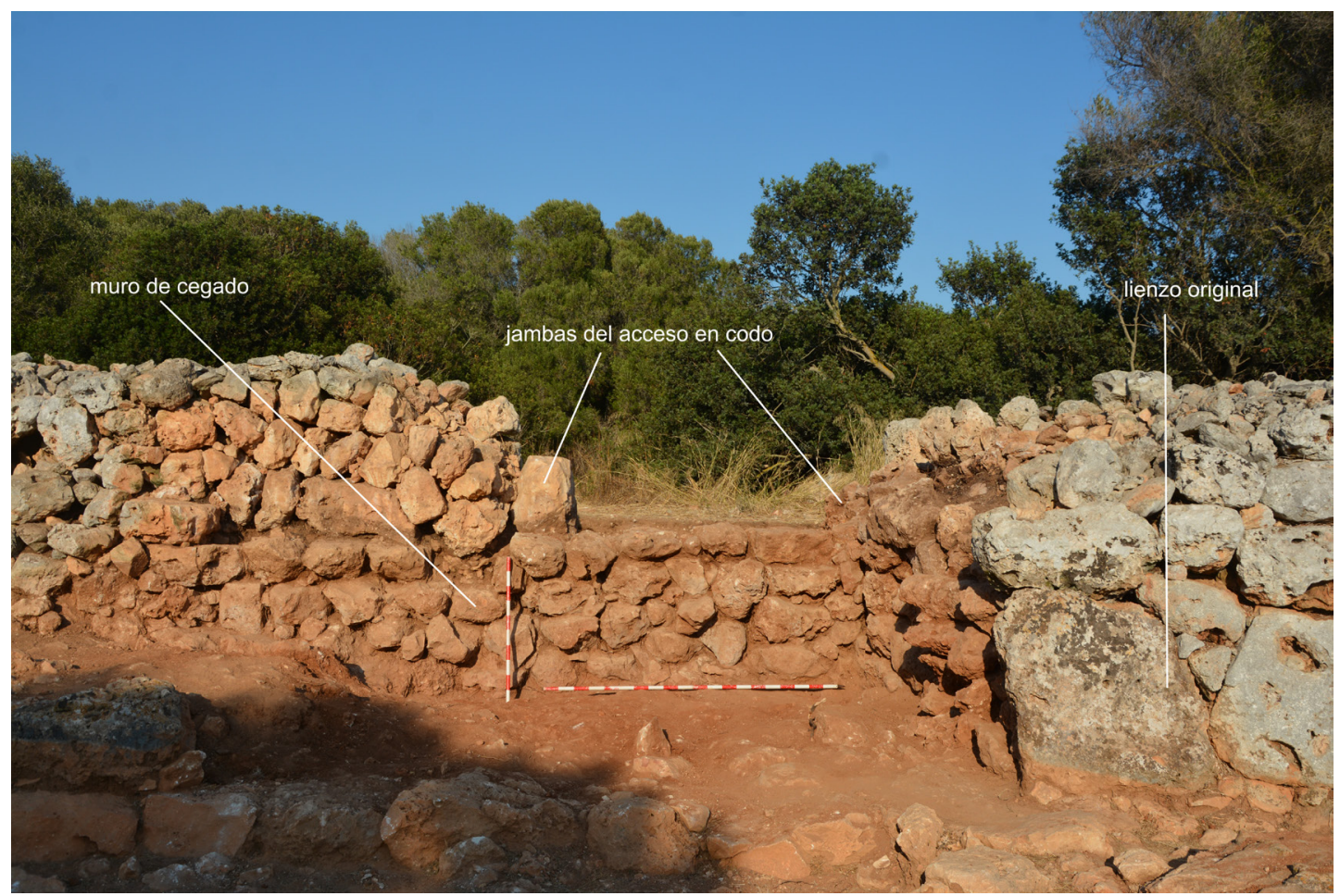

Figura 9. Vano de entrada y muro de cegado de época romana. Fotografía: Proyecto Modular.

localizó un rico lote de materiales, mayoritariamente cerámicos, que se inscriben en un abanico cronológico que abarca la segunda mitad del siglo III a. C. y todo el siglo II a. C. (Fig. 12). De este conjunto, los más antiguos se corresponden con la construcción y uso de la puerta, y los más recientes se adscriben al periodo de conquista romana. Entre estos materiales destaca la presencia de producciones púnico-ebusitanas (ánforas $\mathrm{PE}$ 17 / T-8.1.3.2, PE 22, PE 24, jarras y platos) así como otros materiales itálicos (platos y cuencos de campaniense A) e ibéricos (fragmentos de $\mathrm{ka}$ lathos ibérico pintado y cerámica gris de la costa catalana). Este estrato de arrasamiento alcanzaba el umbral de la puerta, y estaba cubierto por el citado muro que cegó el vano. El muro, al cubrir todo, conformaba un claro terminus antequem tanto para la construcción como para la destrucción de la puerta. Contra este muro apoyaban niveles estratigráficos posteriores en los que se documentan materiales púnico-ebusitanos e itálicos (jarras, ánforas PE 24, ánforas grecoitálicas recientes, fragmentos de cerámicas de cocina itálica, etc.) que se pueden fechar a lo largo de los siglos II y I a. C. (Fig. 10).

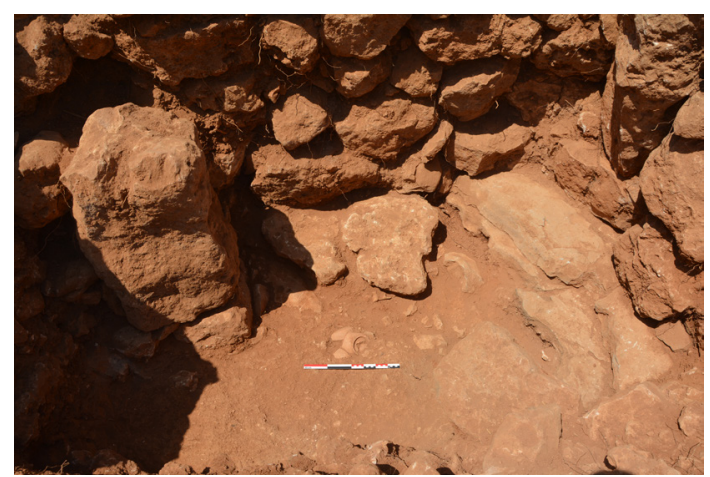

Figura 10. Detalle del proceso de excavación del vano. Cerámica púnico-ebusitana in situ en el nivel de amortización del acceso, junto a una de las jambas. Fotografía: Proyecto Modular.

El registro cerámico indica que, al contrario de lo que sucede en el bando romano durante la II guerra púnica en Hispania, como en los campamentos del Ebro (Noguera et alii, 2014: 39), el material itálico no es mayoritario, sino que el abastecimiento y las provisiones proceden en su mayoría de Ibiza. Tras la amortización de la 


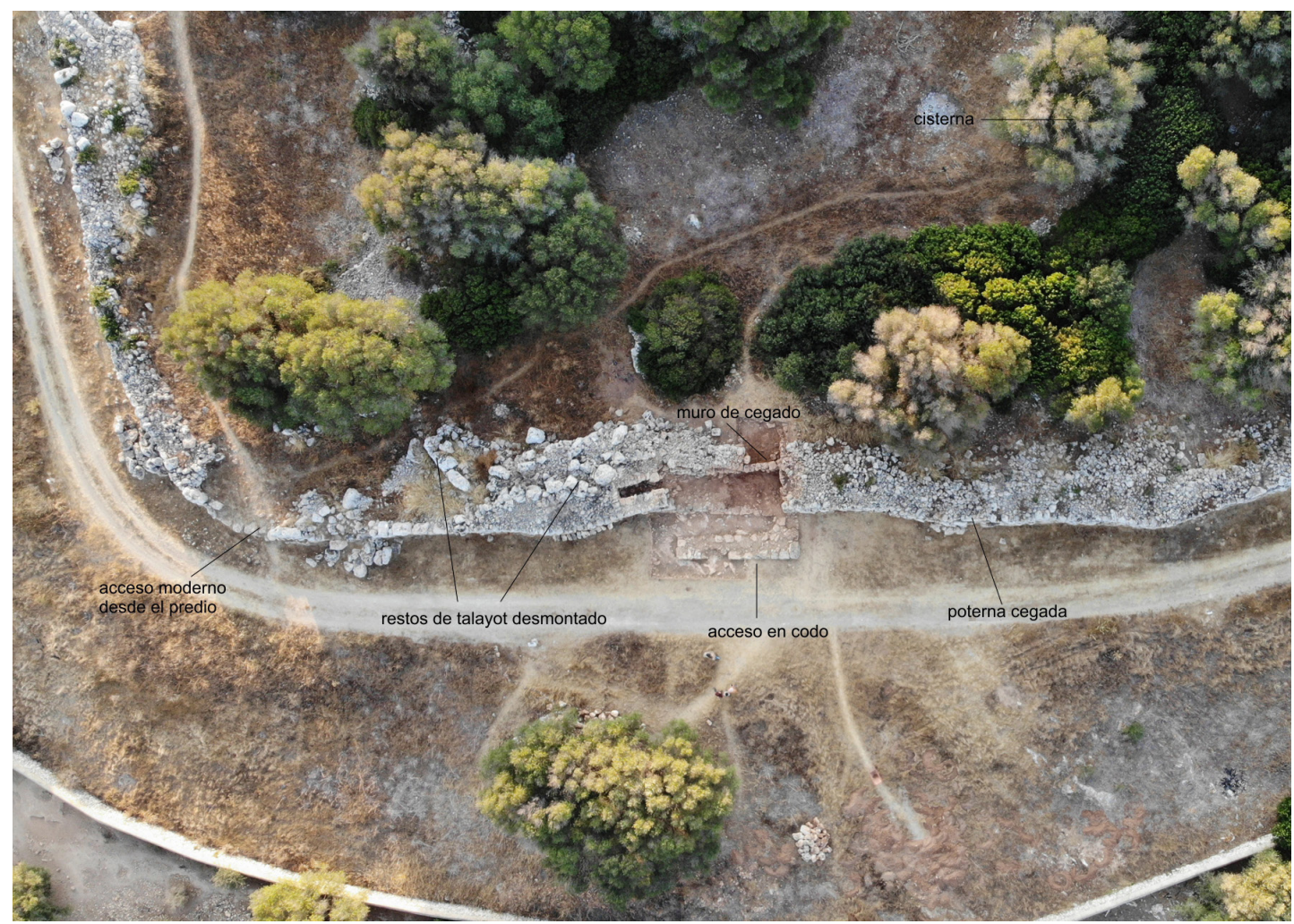

Figura 11. Vista aérea del sector intervenido, con indicación de los elementos citados en el texto. Fotografía: Proyecto Modular.

puerta, que asociamos a la conquista romana, sucederá lo contrario, pues crecen las importaciones itálicas, sobre todo las ánforas (tipos Dressel 1 y grecoitálicas).

Una vez rebasado el umbral de la puerta, hacia el interior, se pudo excavar un interesante lote de elementos vinculados a la primera presencia militar romana, que pasamos a comentar (Fig. 13). Entre estos materiales aparecieron dos glandes de plomo de unos $70 \mathrm{~g}$ de peso cada uno (unas 16 dracmas) y que, aunque por su tamaño podrían ser tardíos - época sertoriana-, también pueden fecharse hacia el 200 a. C. ${ }^{2}$ (siguiendo la propuesta de Quesada et alii, 2015: 352, sobre la coexistencia en este momento de dos metrologías de glandes, uno del doble de peso de la otra, es decir, 8 y 16 dracmas). Sin duda esta última fecha encajaría mejor con nuestro contexto. También apareció un engaste esférico de fayenza y un anillo de bron-

${ }^{2}$ Aunque también se conocen de este peso en el campamento del Ebro, fechado hacia el 210 a. C. (Noguera, 2008: fig. 5; Noguera et alii, 2013: 49 y fig. 19)

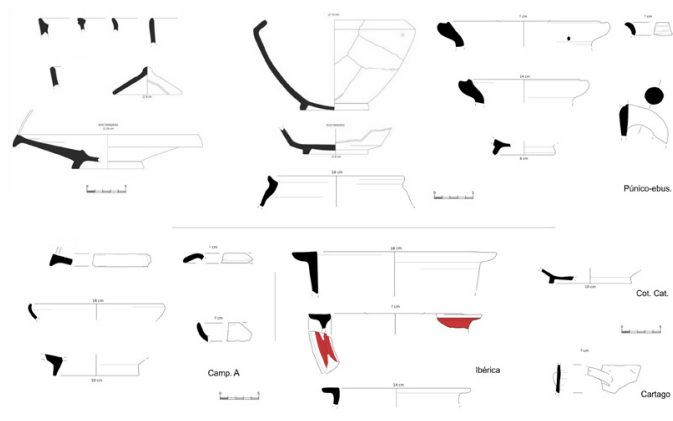

Figura 12. Nivel de sellado del acceso (s. II a. C.). Material púnico-ebusitano (c. común, platos, jarras y ánforas T-8.1.3.3), Campaniense A (formas 23, $27 \mathrm{y}$ 38) e ibéricas (Kalathos, Cot.Cat. forma Cp.1 y cocina púnica). Dibujo: Proyecto Modular.

ce. Como parte del mismo conjunto se hallaron dos elementos quirúrgicos: una paleta de fricción o coticulus de pizarra, para afilar instrumental, y una espátula-punzón de hueso o estilete (Fig. 13). Estos últimos elementos sanitarios son típicos de las valetudinaria (Jackson, 2011; Swift, 2011) y 

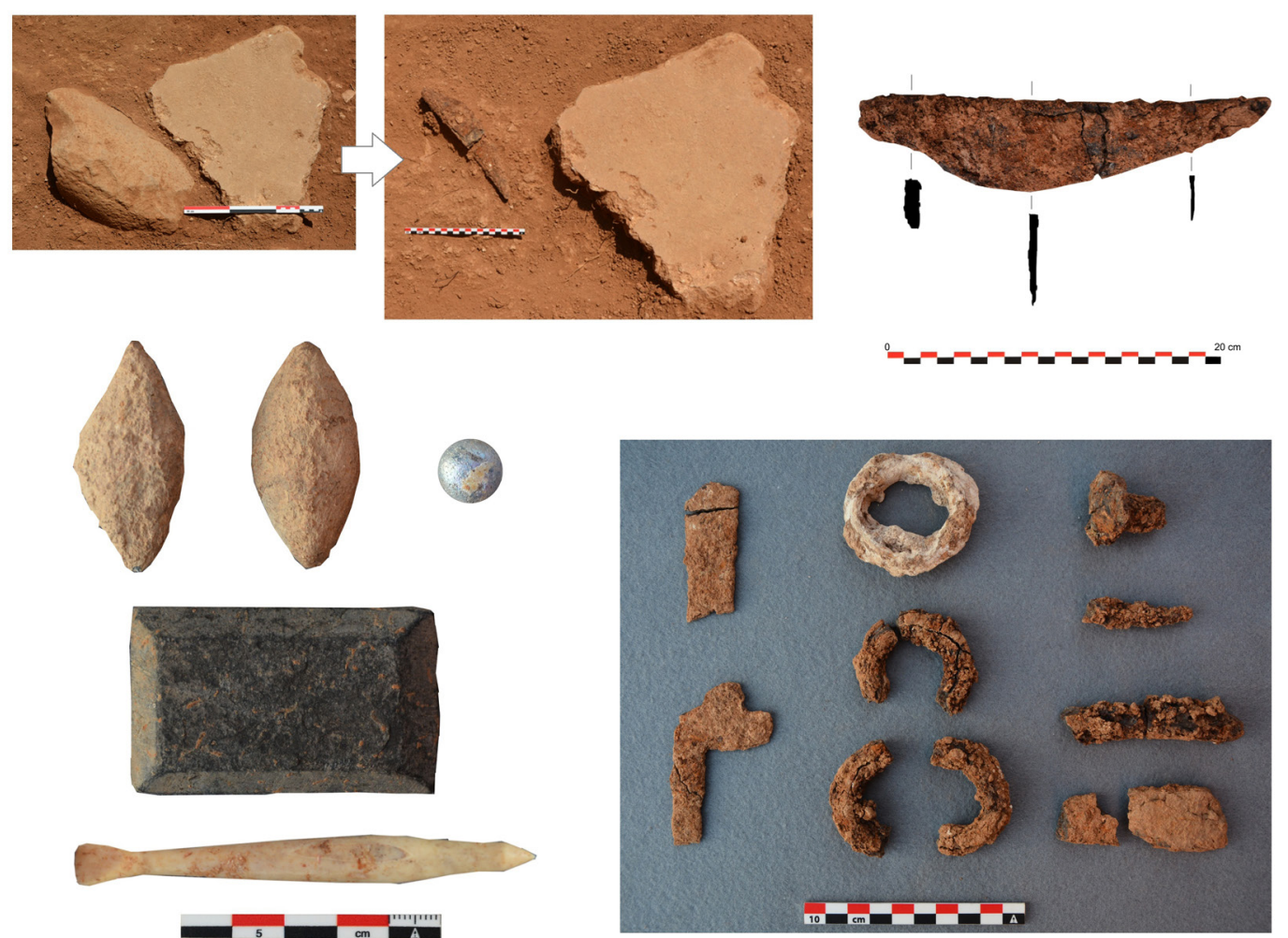

Figura 13. Nivel de amortización del acceso. Cuchillo de hierro y su hallazgo. Debajo, los glandes de plomo y el engaste, la cotícula de piedra y la espátula de hueso. A la derecha, herrajes y remaches de la puerta junto a posibles elementos de escudo (¿soportes de telamón?). Fotografía: Proyecto Modular.

se documentan en contextos militares similares (De Nicolás, 2020) como los de Puig Ciutat (Oristà, Barcelona) $)^{3}$. También se documentan estiletes de hueso, con punta para escribir y espátula para borrar, en similares contextos cronológicos y funcionales (por ej. Bianchi, 1995; Mota et alii, 2014).

En el nivel que se corresponde con la amortización de la puerta, destaca el hallazgo de un cuchillo de hierro de unos $22 \mathrm{~cm}$-incluyendo el mango-, de tipo itálico, con dorso recto sin vaceos ni filo dorsal, similar a los de la necrópolis de La Peschiera de Todi (Quesada, 1991: 505) que se conservan en el museo de Vila Giulia ${ }^{4}$. El cuchillo apareció colocado intencionadamente bajo un molino de piedra típicamente talayótico, que se asociaba al sellado de la puerta. El gesto

\footnotetext{
3 http://www.puigciutat.com/es/museo-virtual/

${ }^{4}$ Debemos esta apreciación al Prof. Fernando Quesada (UAM), a quien siempre agradecemos su inestimable ayuda.
}

claramente voluntario de poner el cuchillo sobre el suelo y colocar encima de forma cuidadosa un molino, podría indicar un ritual de amortización (Fig. 13, arriba). Claro que no es comparable con otros rituales documentados en accesos, como el de la Bastida de Moixent, mucho más rico en armamento (Vives-Ferrándiz et alii, 2015: 291), pero sí es llamativo que al igual que en el caso valenciano, este hallazgo apareció junto a las evidencias del incendio de la puerta con restos de los herrajes in situ, así como de posibles elementos de armamento, claramente termoalterados (Fig. 13, abajo a la derecha).

Los niveles más antiguos excavados, que se asocian a la apertura del vano sobre la muralla y a la construcción del acceso en codo, presentan materiales importados propios del siglo III a. C. Una vez más se trata de cerámica púnico-ebusitana junto a fragmentos de vasos talayóticos (Fig. 14). Destaca la presencia de un borde de ánfora PE 15 / T-8.1.2.1 junto a otros fragmentos de cerámica común ebusitana de la misma cronología 
(Ramon, 2012). Aunque nuestras intervenciones en Son Catlar han ofrecido por lo general unos escasos porcentajes de cerámicas de producción local, cabe referir que en este estrato sí han aparecido diversos fragmentos de cerámica a mano talayótica, que relacionamos con el desmonte de la muralla original del siglo VI a. C. para abrir la puerta en codo, acción que pudo hacer aflorar estos materiales más antiguos que se entremezclan con los del siglo III a. C. (Fig. 14).

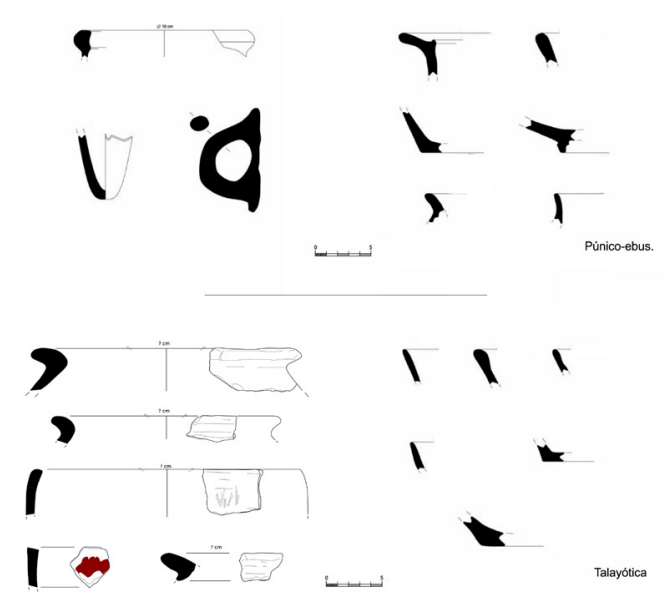

Figura 14. Niveles de construcción del acceso en codo (s. III a. C.). Cerámica púnico-ebusitana (ánfora T-8.1.1.1, c. común) y talayótica. Dibujo: Proyecto Modular.

Habíamos mencionado antes que justo delante de la puerta, a poco más de un metro de distancia del umbral existente entre la muralla y el parapeto, se excavó una pequeña fosa en la que se habían depositado restos humanos de un individuo de cierta edad, a tenor de las evidencias de artrosis visibles, con partes en conexión anatómica, en concreto la columna vertebral y las costillas, y que no conservaba el cráneo. Es evidente que se trató de un depósito intencionado, y que el lugar para enterrarlo fue bien escogido (Fig. 15). El laboratorio ha precisado una fecha de mediados del siglo III a. C. para su muerte (muestra BETA538432, 309-209 cal BC). Este contexto y su datación abren nuevas perspectivas interpretativas, $\mathrm{y}$ por vez primera se detecta en Son Catlar una posible evidencia de violencia física o quizás un ritual asociado a este horizonte militar. Pero por ahora no podemos añadir más sin entrar en la mera especulación, salvo que tanto el radiocarbono como la estratigrafía vinculan este depósito con el momento de la construcción de la puerta en codo.

Por lo descrito, todo el sector presentaba tres fases grosso modo, la original, con la muralla primitiva realizada a partir de un doble paramento de grandes ortostatos verticales rellenados con piedra menuda, posteriormente el desmonte de la muralla y la transformación de esta en un acceso acodado o en bayoneta bien resguardado, y finalmente, el arrasamiento y amortización de este. Una última fase, menos interesante ahora, era la de las transformaciones modernas que hemos descrito ligadas al uso agrícola del predio de Son Catlar. Lo más importante es que de estas tres fases referidas, la excavación ha permitido localizar evidencias suficientes, tanto arquitectónicas como materiales.

Entrando a valorar ahora el acceso en codo y habida cuenta de su estructura y cronología, es el momento de examinar modelos similares. Puertas en codo de esta fecha no se han excavado demasiadas, y las publicaciones tampoco han sido muy precisas. En contextos púnicos ya mencionábamos antes que, a excepción del acceso a la ciudad de Carteia, tan solo podemos contar con el de la "porte du Couchant" de Kerkouane, en el Cap Bon tunecino (Fantar, 1986; Prados, 2008: 35). En ambos ejemplos el acceso estaba acompañado de pequeños departamentos, a modo de cuerpos de guardia. En Son Catlar la pequeña garita que jalona el acceso pudo funcionar de manera similar, ya que pese a su tamaño reducido era suficiente para almacenar armas y para que un soldado reposase a la espera de dar relevo (Fig. 15). Aunque este tipo de puerta se conoce desde mucho antes en oriente (Rey, 2016: 38), los paralelos más próximos y anteriores a la época romana hay que buscarlos en el Egeo, desde el siglo V a. C. y en época helenística (Winter, 1971), como por ejemplo la puerta de la ciudad cretense de Lato (Baldwin-Bowsky, 1989) y en diversos enclaves de Anatolia como Kerkenes o Alisar, en sus fases de la Edad del Hierro (Vergnaud, 2016: 100). Los accesos a los enclaves fenicios eran directos, y estaban flanqueados por torres cuadradas o rectangulares (Montanero y Asensio, 2009: 200). Las puertas en codo serán finalmente más frecuentes a partir del siglo II a. C.; solo en el caso hispano se conocen magníficos ejemplos como los de Numancia o Lucentum (Jimeno et alii, 2016; Olcina et alii, 2017).

Aunque presentaba dos portones, uno al inicio del codo que dejó huella en la roca base, y otro delimitado por jambas de piedra y del que se ha- 

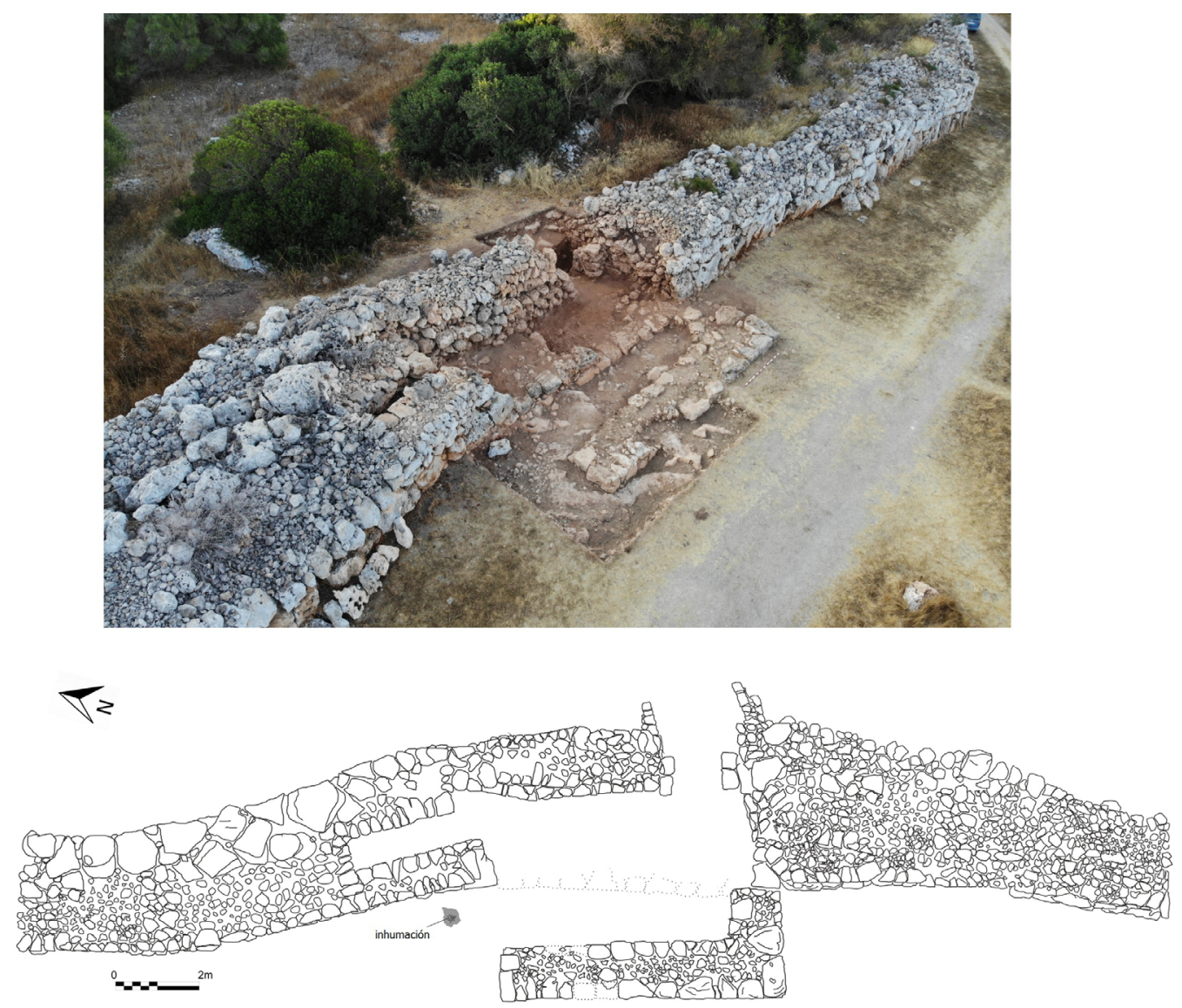

Figura 15. Vista oblicua y planta del acceso en codo al finalizar la intervención. Fotografía y dibujo: Proyecto Modular.

llaron los herrajes, la puerta de Son Catlar era sencilla, y pudo estar construida con cierta premura. Con menos de $2 \mathrm{~m}$ de luz, somos conscientes de que la puerta es de reducido tamaño, pero no por ello menos relevante (Fig. 15). No se trató de un acceso principal a la ciudad, como en el caso de Carteia, o cómodo y funcional, sino que más bien era una poterna protegida, enmascarada por un parapeto para dar respuesta a una demanda precisa: poder moverse sin ser visto $\mathrm{y}$, al obligar el giro, dificultar el paso y evitar su derribo con un ariete. Las fechas que provee la excavación remiten una vez más al conflicto romano-cartaginés, como ya hemos visto en el caso de los bastiones intervenidos, y la sucesión de descubrimientos que hemos detallado, su clara adscripción al bando púnico, que tendría en estos poblados a sus aliados (quizás forzosos) como se desprende de los comentarios de Tito Livio (XXII, 20; XXIII, 40; XXIII, 41 y sobre todo XXVII, 20).

\section{CONCLUSIÓN}

Si la poliorcética es el arte de atacar y defender plazas fuertes, como tal entendemos la actuación desarrollada en Son Catlar. La apertura de este acceso fortificado ha de ser enmarcada en un contexto preciso, si se tiene en cuenta su funcionalidad específica. Decíamos antes que la puerta estaba configurada para poder salir y entrar sin ser visto, debido a que quedaba enmascarada por el parapeto. Desde la distancia, era imposible distinguir la existencia de un vano, que es siempre la parte más débil de una fortificación. Esta lectura ha de ser acompañada con lo que se ha visto en los otros sectores intervenidos del encintado. 
Decíamos que Son Catlar, con su perímetro de cerca de $1 \mathrm{~km}$ conservado, permite estudiar cómo se organiza de forma completa la defensa de un núcleo habitado, al contrario que en otros yacimientos, algunos fundamentales en este periodo como puede ser la propia Cartagena, donde apenas se cuenta con algún tramo de muralla excavado. Antes se señalaba que los bastiones adosados al lienzo original podían permitir la ubicación de artillería de torsión, y los adarves su circulación intramuros. Tanto estas construcciones como la maquinaria tenían una clara función disuasoria, y recordemos que no hay fortificación más eficaz que la que nunca fue atacada.

El conjunto de la muralla de Son Catlar parece estar provisto de un sistema de contraataque y contención pensado para defenderse de un enemigo que tenía la capacidad de asediar, y ese debió de ser Roma a tenor de lo que dicta el contexto histórico y el registro arqueológico. De hecho, este poblado está ubicado en una zona elevada próxima al mar, pero bastante llana (Figs. 1 y 2), que permitiría el acceso hasta la muralla con maquinaria de guerra. La balística alejaría la ubicación de los potenciales campamentos enemigos, y la distancia sería ideal para que el acceso en codo excavado quedase perfectamente mimetizado. Solo así se podría entender el esfuerzo emprendido y el bloqueo de vanos cercanos. También el inmediato arrasamiento tras la conquista romana y el cegado de todo el conjunto mediante un muro. Durante un periodo, al menos la segunda mitad del siglo III y la primera del II a. C. el poblado tuvo dos accesos, el principal, ubicado en el lado oriental, y este. Tras la conquista romana del 123 a. C., la referida amortización dejó solo en uso, por lo que sabemos hasta ahora, el acceso principal, que conocemos como "puerta norte".

La concatenación de todos los elementos descritos junto a la documentación textual nos lleva a atribuir una génesis púnica, probablemente bárquida, a esta construcción, que habría sido ejecutada con mano de obra local fundamentalmente. Será seguramente imposible precisar si se puede vincular con las estancias de Magón en Menorca ${ }^{5}$ o si se levantó antes, durante la I guerra púnica.

\footnotetext{
${ }^{5}$ Magón ya conocía las Baleares con anterioridad al año 206 a. C. Tito Livio (XXVII, 20, 7) alude a una primera visita al archipiélago del menor de los Barca para reclutar mercenarios en el 208 a. C., justo después de librarse la batalla de Baecula en la campiña jiennense.
}

Algunos trabajos clásicos señalaron que hacia el año 252 a. C. los insulares se rebelaron contra una guarnición cartaginesa. Ello habría motivado el viaje en persona de Amílcar Barca para sofocar el alzamiento y para asegurar nuevas levas de mercenarios (Prados y Jiménez, 2017: 110). De forma general se reconoce que la isla fue adepta a la causa de Cartago (Sánchez, 2003; Castrillo, 2005; Guerrero et alii, 2006; Costa, 2015). Al respecto, es determinante el momento en que Menorca acogió a la flota comandada por Magón en el invierno de 206-205 a. C., en el seguro puerto donde estableció el campamento que dio origen a la ciudad homónima de Mago. Tras la derrota de Cartago en Zama que puso fin a la II guerra púnica (202 a. C.), aún es factible enmarcar Menorca dentro de la órbita púnica, pero ligada económicamente a Ibiza. La isla mantendría pese a ello cierta independencia —o desgobierno- que posibilitó la recepción de piratas que fondearon en sus recónditas calas, dificultando la navegación comercial romana. Esta actividad de bandidaje motivó, al menos formalmente, su conquista definitiva ordenada por el senado de Roma y acometida por Metelo (Orfila, 2008).

Creemos que las excavaciones arqueológicas desarrolladas en este enclave vienen a incrementar el conocimiento de este periodo y se suman al cada vez más rico dosier documental sobre las guerras púnicas. La ciencia arqueológica es hoy día, gracias a la realización de proyectos sistemáticos como este, apoyado firmemente por el Consell Insular, la que más información novedosa está aportando sobre el conflicto entre Cartago y Roma. El hallazgo, excavación y futura musealización de este acceso contribuirán a clarificar las preguntas científicas que se planteaban al inicio y que pondrán de manifiesto el protagonismo que Menorca tuvo también en esta etapa decisiva de la historia antigua del Mediterráneo.

\section{FUENTES}

Tito Livio (1993): Historia de Roma desde su fundación. Libros XXI-XXV. Trad. y notas de J.A. Villar Vidal. Biblioteca Clásica Gredos 176. Madrid, Editorial Gredos.

Tito Livio (1993): Historia de Roma desde su fundación. Libros XXVI-XXX. Trad. y notas de J.A. Villar Vidal. Biblioteca Clásica Gredos 177. Madrid, Editorial Gredos. 


\section{BIBLIOGRAFÍA}

Baldwin-Bowsky, M. W. (1989): «Portrait of a Polis: Lato Pros Kamara (Crete) in the Late Second Century B. C.». Hesperia, 58.3: 331-347. https://doi. org/10.2307/148222

Berrocal-Rangel, L. (2004): «La defensa de la comunidad: sobre las funciones emblemáticas de las murallas protohistóricas en la península ibérica». Gladius, XXIV: 27-98. https://doi.org/10.3989/ gladius. 2004.36

Bianchi, C. (1995): Spilloni in osso di età romana. Problematiche generali e rinvenimenti in Lombardia. Milano, Collana di Studi di Archeologia Lombarda.

Blánquez Pérez, J.; González Reyero, S. y Prados Martínez, F. (2006): «Lectura estratigráfica. Excavación del Corte C2. Sector Púnico», L. Roldán, M. Bendala, J. Blánquez y S. Martínez (dirs.), Estudio histórico-arqueológico de la ciudad de Carteia (San Roque, Cádiz). 1994-1999. Arqueología Monografías, 24, vol. I. Madrid, Junta de Andalucía, Universidad Autónoma de Madrid: 133-142.

Carbonell Pastor, S. (2017): «Avance en la investigación del mundo funerario Postalayótico menorquín en el marco del Proyecto Modular: hipogeos y problemática de estudio», M. Anglada, M. Riera y A. Martínez (coords.), VII Jornades d'Arqueología de les Illes Balears. Mahón, Consell Insular de Menorca: 173-178.

Castrillo Villa, M. (2005): «Fenicis i púnics a Menorca: Vint-i-cins anys d'investigació i noves dades aportades per les àmfores feniciopúniques a l'illa». J. Ramon (coord.), Fenicis i púnics als Països Catalans. Fonaments, Prehistòria i Món Antic als Països Catalans, 12. Barcelona, Generalitat de Catalunya: 149-168.

Cecchini, S. M. (1995): «Architecture militaire, civile et domestique partim Orient», V. Krings (coord.), La civilisation phénicienne \& punique. Manuel de recherche. Leiden, Brill: 389-395.

Costa Ribas, B. (2015): «Un hivern a Menorca. Magó Barca a l'arxipèlag Balear, de la tardor de l'any 206 a l'estiu del 205 a. C.», C. Andreu, C. Ferrando y O. Pons (coords.), L'entreteixit del temps. Miscel-lània d'estudis en homenatge a Lluís Plantalamor Massanet. Palma de Mallorca, Consell Insular de Mallorca: 125-150.

De Nicolás Mascaró, J. C. (2014): «Amuletos, colgantes y cuentas de pasta vítrea de collares púnicos en Menorca», B. Costa (coord.), In Amicitia. Miscel. lania d'estudis en Homenatge a Jordi H. Fernández. Trabajos del Museo Arqueológico de Ibiza y Formentera, 72. Ibiza, Museo Arqueológico de Ibiza y Formentera: 205-219.

De Nicolás Mascaró, J. C. (2017): «Gallos, labrys y campanillas. Elementos simbólicos de la religión púnico-talaiótica balear», F. Prados y F. Sala (eds.), El oriente de occidente, fenicios y púnicos en el área ibérica. Alicante, Publicaciones de la Universidad de Alicante: 433-464.

De Nicolás Mascaró, J. C. (2020): De les cotícules $i$ espàtules mèdiques i cosmètiques. Arqueomenorca, Monografies, 25. Maó, Arqueomenorca.

Domínguez Monedero, A. J. (2014): «Piratería en Magna Grecia y Sicilia, mecanismos de prevención y contención», A. Álvarez-Ossorio, E. Ferrer y E. García (coords.), Piratería y seguridad marítima en el Mediterráneo antiguo. SPAL Monografías, XVII. Sevilla, Universidad de Sevilla, Secretariado de Publicaciones: 67-86.

Fantar, M. H. (1986): «Fortification punique: les murailles de Kerkouane», P. Leriche y H. Tréziny (eds.) La fortification dans l'histoire du monde grec. Colloque de Valbonne, 1982, Paris: 241-250.

Frederiksen, R. (2011): Greek city walls of the Archaic Period, 900-480 BC. Oxford, Oxford University Press.

Garlan, Y. (1992): «La fortification, un fait de civilisation». Les Dossiers d'Archéologie, 172: 36-41.

Greco, E. y Torelli, M. (1983): Storia dell'Urbanistica. Il Mondo Greco. Milano, Editori Laterza.

Guerrero Ayuso, V. M.; Calvo Trías, M. y Gornés Hachero, S. (2006): Historia de las Islas Baleares 2. Mallorca y Menorca en la $2^{a}$ Edad del Hierro. La cultura Talayótica y Postalayótica. Palma de Mallorca, El Mundo-El Día de Baleares.

Guerrero Ayuso, V. M.; Calvo Trías, M. y Salvà Simonet, B. (2002): «La cultura talayótica: Una sociedad de la Edad del Hierro en la periferia de la colonización fenicia». Complutum, 13: 221-258.

Jackson, R. (2011): «Medicine and hygiene», L. Allason-Jones (ed.), Artefacts in Roman Britain. Their purpose of use. Cambridge, Cambridge University Press: 243-268.

Jiménez Vialás, H.; León Moll, M. J.; Prados Martínez, F. y Torres Gomariz, O. (2019): Son Catlar. Plan Director. Investigación, difusión y puesta en valor. Mahón, Consell Insular de Menorca.

Jiménez Vialás, H.; Prados Martínez, F.; De Nicolás Mascaró, J. C.; Adroher Auroux, A. M.; Torres Gomariz, O.; Martínez García, J. J.; García Jiménez, I.; López, D.; Expósito, D. y Carbonell Pastor, S. (2017): «Prospección arqueológica en Torrellafuda. $\mathrm{Al}$ encuentro de la Menorca púnica», F. Prados, H. Jiménez y J. J. Martínez (coords.), Menorca entre fenicis i púnics. Menorca entre fenicios y púnicos. Publicaciones del CEPOAT 2, Publicacions des Born 25. Murcia, Universidad de Murcia: 183-202.

Jimeno Martínez, A.; Chaín Galán, A.; Liceras, R. y Quintero Cabello, S. (2016): «La Numancia que resistió a Escipión Emiliano», M. Bendala (coord.), Los Escipiones. Roma conquista Hispania. Alcalá de Henares, Museo Arqueológico Regional: 259273.

Juan Benejam, G.; De Nicolás Mascaró, J. C. y Pons Machado, O. (2004): «Menorca, segle IV - II a. 
C., un mercat per al comerç ebusità», J. Sanmartí (coord.), La circulació d'àmfores al Mediterrani occidental durant la Protohistòria (segles VIII-III a. C.): aspectes quantitatius $i$ anàlisi de contingunts. Calafell, Publicaciones de la Universidad de Barcelona: 261-264.

Juan Fraile, R.; Pons Machado, O. y Juan Benejam, Q. (1998): Memòria de la campanya juny-setembre de 1995. Poblat de Son Catlar. Ciutadella de Menorca, Associació d'Amics del poblat de Son Catlar.

Leriche, P. y Tréziny, H. (1982): La fortification dans l'histoire du monde grec, Actes du Colloque international "La Fortification et sa place dans l'histoire politique, culturelle et sociale du monde grec" (Valbonne, décembre 1982). Paris, Centre National de la Recherche Scientifique.

Montanero Vico, D. y Asensio Vilaró, D. (2009): «Puertas fortificadas del Mediterráneo: orígenes y evolución». Revista d'Arqueologia de Ponent, 19: 177-204.

Moret, P. (1998): «"Rostros de piedra". Sobre la racionalidad del proyecto arquitectónico de las fortificaciones urbanas ibéricas», C. Aranegui (ed.), Actas del Congreso internacional Los iberos, príncipes de occidente. Las estructuras de poder en la sociedad ibérica. Saguntum Extra 1. Valencia, Universidad de Valencia: 83-92.

Mota, N.; Pimenta, J. y Silva, R. B. (2014): «Acerca da ocupação romana republicana de Olisipo: os dados da intervenção na Rua do Recolhimento n. ${ }^{\text {s }}$ 6870». Cira - Arqueologia, 3: 149-177.

Noguera Guillén, J. (2008): «Los inicios de la conquista romana de Iberia: los campamentos de campaña del curso inferior del río Ebro». Archivo Español de Arqueología, 81: 31-48. https://doi.org/10.3989/ aespa.2008.v81.39

Noguera Guillén, J.; Ble Gimeno, J. y Valdés Matías, P. (2013): La Segona Guerra Púnica al nord-est d'Ibèria: una revisió necessària. Barcelona, Societat Catalana d'Arqueologia.

Noguera Guillén, J.; Principal, J. y Ñaco del Hoyo, T. (2014): «La actividad militar y la problemática de su reflejo arqueológico: el caso del Noreste de la Citerior (218-45 a. C.)», F. Cadiou y M. Navarro (eds.), La guerre et ses traces. Conflits et sociétés en Hispanie à l'époque de la conquête romaine (IIIe-Ier s. a. C.). Mémoires, 37. Bordeaux, Ausonius: $31-56$.

Olcina Doménech, M.; Guilabert Mas, A. y Tendero Porras, E. (2017): «Una ciudad bárquida bajo Lucentum (Alicante). Excavaciones en el Tossal de Manises», F. Prados y F. Sala (eds.), El oriente de occidente, fenicios y púnicos en el área ibérica. Alicante, Publicaciones de la Universidad de Alicante: 285-328.

Orfila Pons, M. (1995): «Arqueología Romana», M. Orfila Pons, C. Rita Larrucea, Ll. Plantalamor Massanet y F. Tuset Bertran (coords.), Enciclopedia de
Menorca. Tom VIII. Mahón, Obra Cultural de Menorca: 195-264.

Orfila Pons, M. (2008): «La intervención de Q. Cecilio Metelo sobre las Baleares (123 a 121 a. C.). Condiciones previas y sus consecuencias». Pyrenae, 39.2: 7-45.

Plantalamor Massanet, L1. (1991): L'arquitectura prehistórica i protohistòrica de Menorca i el seu marc cultural. Mahón, Trabajos del Museo de Menorca.

Plantalamor Massanet, L1. y Rita Larrucea, M. C. (1982): «Tres cuevas de la Edad del Bronce en la zona occidental de Menorca». Ampurias, 44: 1-16.

Prados Martínez, F. (2008): «La arquitectura defensiva en Cartago y su área de influencia», B. Costa y J. H. Fernández (coords.), Arquitectura defensiva fenicio-púnica. XXII Jornadas de Arqueología fenicio-púnica (Eivissa, 2007). Trabajos del Museo Arqueológico de Ibiza y Formentera, 61. Ibiza, Museo Arqueológico de Ibiza y Formentera: 25-56.

Prados Martínez, F.; De Nicolás Mascaró, J. C.; Jiménez Vialás, H.; Martínez García, J. J. y Torres Gomariz, O. (2015): «Culturas arquitectónicas púnicas. Menorca como laboratorio de análisis», A. Martínez y G. Graziani (coords.), VI Jornades d'Arqueologia de les Illes Balears. Formentera, Consell Insular de Ibiza y Formentera: 185-193.

Prados Martínez, F. y Jiménez Vialás, H. (2017): «Menorca entre fenicios y púnicos. Una aproximación arqueológica desde la arquitectura defensiva», F. Prados, H. Jiménez y J. J. Martínez (coords.), Menorca entre fenicis i púnics. Menorca entre fenicios y púnicos. Publicaciones del CEPOAT, 2; Publicacions des Born, 25. Murcia, Universidad de Murcia: 107-138.

Prados Martínez, F.; Jiménez Vialás, H.; León Moll, M. J.; De Nicolás Mascaró, J. C.; Adroher Auroux, A. M. y Martínez García, J. J. (2017a): «Menorca entre Cartago y Roma: avance de la excavación arqueológica del Proyecto Modular en el poblado de Son Catlar (Ciutadella)», M. Anglada, M. Riera y A. Martínez (coords.), VII Jornades d'Arqueología de les Illes Balears. Mahón, Consell Insular de Menorca: 153-160.

Prados Martínez, F.; Jiménez Vialás, H. y Martínez García, J. J. (coords.) (2017b): Menorca entre fenicis i púnics. Menorca entre fenicios y púnicos. $\mathrm{Pu}$ blicaciones del CEPOAT, 2; Publicacions des Born, 25. Murcia, Universidad de Murcia.

Puig Palerm, A. (2013): «La piratería en el archipiélago balear en la Antigüedad: ¿sólo una causa de intervención romana del 123 a. C.?», A. ÁlvarezOssorio, E. Ferrer y E. García (eds.), Piratería y seguridad marítima en el Mediterráneo antiguo. SPAL Monografías, XVII. Sevilla, Publicaciones de la Universidad de Sevilla: 145-166.

Quesada Sanz, F. (1991): «En torno al origen y procedencia de la falcata ibérica», J. Remesal y O. Musso (coords.), La presencia de material etrusco en la 
Península Ibérica. Barcelona, Publicaciones de la Universidad de Barcelona: 475-541.

Quesada Sanz, F. (2007): «Asedio, sitio, asalto... aspectos prácticos de la poliorcética en la Iberia prerromana», L. Berrocal-Rangel y P. Moret (coords.), Paisajes fortificados de la Edad del Hierro: las murallas protohistóricas de la meseta y de la vertiente atlántica en su contexto europeo (Actas del coloquio celebrado en la Casa de Velázquez, octubre de 2006). Madrid, Casa de Velázquez: 75-98.

Quesada Sanz, F.; Gómez Cabeza, F.; Molinos Molinos, M. y Bellón Ruiz, J. P. (2015): «El armamento hallado en el campo de batalla de Las Albahacas-Baecula», J. P. Bellón, A. Ruiz, M. Molinos, C. Rueda y F. Gómez (eds.), La Segunda Guerra Púnica en la península ibérica. Baecula: arqueología de una batalla. Jaén, Publicaciones de la Universidad de Jaén: 311-396.

Ramallo Asensio, S. F.; Ruiz Valderas, R.; Murcia Muñoz, A. J. y Guillermo Martínez, M. (2013): «Aproximación a las fases de ocupación de Cartagena a partir del registro arqueológico obtenido en las intervenciones del teatro romano: breve síntesis de su evolución urbana». Anales de Prehistoria y Arqueología de la Universidad de Murcia, 29: 23-56

Ramis Bernad, D. (2017): «Evidències de contactes exteriors al món talaiòtic a partir de l'estudi del registre faunístic», F. Prados, H. Jiménez y J. J. Martínez (coords.), Menorca entre fenicis i púnics. Menorca entre fenicios y púnicos. Publicaciones del CEPOAT, 2; Publicacions des Born, 25. Murcia, Universidad de Murcia: 203-219.

Ramon Torres, J. (1995): Las ánforas fenicio-púnicas del Mediterráneo Central y Occidental. Barcelona, Publicaciones de la Universidad de Barcelona.

Ramon Torres, J. (2012): «La cerámica púnico-ebusitana en época tardía (siglos III-I a. C.)», D. Bernal y A. Ribera (coords.), Cerámicas hispanorromanas II. Producciones regionales. Cádiz, Publicaciones de la Universidad de Cádiz: 583-617.

Ramon Torres, J. y Pons Machado, O. (2017): «Materiales inéditos de los siglos VI-II a. C. procedentes de Ibiza conservados en el Museo de Menorca». Materialidades. Perspectivas actuales en cultura material, 5: 91-120.

Rey, S. (2016): «Mesopotamian Poliorcetics Before Assyria: Genesis of the Art of Fortification and Siege Warfare», R. Frederiksen, S. Müth, P. Schneider y M. Schnelle (eds.), Focus on Fortifications. New Research on Fortifications in the Ancient Mediterranean and the Near East. Monographs of the Dan- ish Institute at Athens, 18. Oxford \& Philadelphia, Oxbow Books: 34-42.

Ruiz Valderas, E. (2004): «Cerámicas campanienses de Cartagena: el registro arqueológico y el registro comercial», M. Lechuga (ed.), Scombraria. La Historia oculta bajo el mar. Murcia, Museo Arqueológico de Murcia: 89-106.

Ruiz Valderas, E.; Murcia Muñoz, A. J.; Ramallo Asensio, S. F. y Guillermo Martínez, M. (2013): «Testimonios de época bárquida procedentes de las excavaciones en el teatro romano de Cartagena». Anales de Prehistoria y Arqueología de la Universidad de Murcia, 29: 57-69.

Sánchez León, M. L. (2003): «La ciudad de Mago (Maó, Menorca): continuidades y rupturas». $M a-$ yurqa, 29: 97-109.

Swift, F. (2011): «Personal Ornaments», L. AllasonJones (ed.), Artefacts in Roman Britain. Their purpose of use. Cambridge, Cambridge University Press: 194-208.

Torres Gomariz, O. (2016): «De arqueología menorquina: Maria Lluïsa Serra Belabre y los círculos talayóticos de Sant Vicenç d'Alcaidús (Alaior, Menorca)». Panta Rei. Revista Digital de Ciencia y Didáctica de la Historia, 2016: 19-36. https://doi. org/10.6018/pantarei/2016/2

Torres Gomariz, O. (2017): «Cercles menorquins. Aproximación a la influencia de la arquitectura púnica en las viviendas postalayótica de Menorca», F. Prados, H. Jiménez y J. J. Martínez (coords.), Menorca entre fenicis $i$ púnics. Menorca entre fenicios y púnicos. Publicaciones del CEPOAT, 2; Publicacions des Born, 25. Murcia, Universidad de Murcia: 235-248.

Vergnaud, B. (2016): «Fortifications of Central Anatolia in the Early First Millennium BC», R. Frederiksen, S. Müth, P. Schneider y M. Schnelle (eds.), Focus on Fortifications. New Research on Fortifications in the Ancient Mediterranean and the Near East. Monographs of the Danish Institute at Athens, 18. Oxford \& Philadelphia, Oxbow Books: 94-108.

Vives-Ferrándiz, J.; Iborra, P.; Bonet, H.; Pérez, G.; Carrión, Y.; Quesada, F.; Ferrer, C. y Tortajada, G. (2015): «Ofrendas para una entrada: un depósito ritual en la Puerta Oeste de la Bastida de les Alcusses (Moixent, Valencia)». Trabajos de Prehistoria, 72.2: 282-303. https://doi.org/10.3989/ tp. 2015.12155

Winter, F. E. (1971): Greek Fortifications. London, Routledge \& Kegan Paul. 
